\title{
On the Anatomy of Danaea and other Marattiaceae.
}

BY

\author{
GEORGE BREBNER, \\ Lecturer in Botany, University College, Bristol.
}

With Plates XXII and XXIII, and Text-Figures 28 and 29.

INTRODUCTION.

THIS investigation was begun in the Jodrell Laboratory, Royal Botanic Gardens, Kew, in I893, at the suggestion of the Honorary Keeper, Dr. D. H. Scott. In connexion with it two papers were published, one on the development of the mucilage-canals of the Marattiaceae ${ }^{1}$, and another on the prothallus and embryology of Danaea simplicifolia, Rudge ${ }^{2}$. It was originally proposed to make the general anatomical part a comparative study of the then known genera of the Marattiaceae. Its completion, however, was unavoidably delayed, and now it is found desirable to limit its scope somewhat on account of some recent detailed work on the Anatomy of Angiopteris evecta ${ }^{3}$.

1 Journ. Linn. Soc., xxx.

2 Annals of Botany, x, I 896 .

${ }^{3}$ R. F. Shove, On the structure of the stem of Angiopteris evecta, Annals of Botany, xiv, 1900. J. Bretland Farmer and T. G. Hill, On the Arrangement and Structure of the Vascular Strands in Angiopteris evecta and some other Marattiaceae, Annals of Botany, xvi, I902.

[Annals of Botany, Vo1. XVI. No. LXIII. September, 1902.] 
For the purposes of this investigation, material, more or less complete, was available of species of Danaea, Angiopteris, Marattia and Kaulfussia, for which the writer is greatly indebted to Sir William Thiselton-Dyer, Director of the Royal Botanic Gardens, Kew, Professor F. O. Bower, Glasgow University, Professor F. W. Oliver, University College, London, and the late Mr. George S. Jenman, British Guiana. The writer likewise had the privilege of cutting a section of the petiole of a herbarium specimen of the new genus Archangiopteris, discovered by Henry in $1899^{1}$.

The subject will be dealt with in the following order:-

(I) Development of the vascular system of Danaea simplicifolia, Rudge.

(2) Comparative anatomy of the frond, stem and root of the Marattiaceae.

The importance of the Marattiaceae as a group and the desirability of studying it both from the developmental, anatomical and palaeontological aspects has been so well set forth in the important recent contributions just referred to, that further dwelling on this point is unnecessary. It is hoped that the present paper will help to fill up another gap or two in our knowledge of this interesting section of the Pteridophyta, although from the nature of all such investigations there can be no finality.

It will be well, however, before beginning the descriptive part of this paper, to say a few words about the stelar terminology to be used. The exceedingly valuable advance made by Van Tieghem in emphasizing the importance of the vascular conducting cylinder as a whole by his stelar terminology has been recognized by the general adoption of his terms. Also, owing to the influence of the fresh position thus assumed, a great step forward has been taken in the study and comprehension of the vascular system of plants. This study, in its turn, has led to the recognition of the fact, that a certain number of the terms did not fit the resulting new views. Further, fresh terms have been devised to express

1 Christ u. Giesenhagen, Flora, I 899. 
the new theoretical interpretations. Strasburger's term phloeoterma and Jeffrey's siphonostele may be cited as examples of these. The original, as well as the later terms, have in some respects the unfortunate character that they are not merely descriptive, and therefore cannot be used in many cases where they would be very useful if they did not commit the user to expressing homologies which he did not wish to imply. It seems desirable therefore, in this connexion, that certain names should be found, which denote definite structures without necessarily involving any idea of homology. The advantages of some such way out of the difficulty seem to counterbalance the disadvantages of a further multiplication of terms.

In the terminology to be used in the present paper the word 'stele' and several of its compounds will be employed in their original sense, in most cases, but several others have been devised to fill certain apparent gaps.

The Dicotyledons are looked upon as the highest expression of plant life, and it therefore seems appropriate to apply the term eustele to their well-known type of vascular cylinder, i.e. a ring of collateral vascular bundles surrounding a pith and limited on the outside by the pericycle. Eustele is therefore equivalent to Van Tieghem's 'monostele' in one of its applications. This definition is adopted so that E. C. Jeffrey's term of siphonostele may not be interfered with, because from his point of view the pith is extrastelar. In most roots the arrangement of the xylem and phloem is 'radial,' hence the term actinostele seems appropriate. Its application, however, would not be confined to roots (cf. stem of Lycopodium). Certain supposed primitive steles have been called protosteles, but at least two distinct kinds are included under this name, viz. what is here called an actinostele and also another simpler type in which a ring of phloem surrounds a mass of central tracheids (e.g. most Hymenophyllaceae). On account of its structural simplicity haplostele will be used for the latter type, and, if a central mass of parenchyma is present, the structure can be spoken of as a medullated haplostele (e. g. most Lepidodendreae). The adoption of this word leaves protostele and 
protostelic to be used as previously. When distinctly present, and developed from the procambium-strand along with the other elements, the 'pericycle' would be included in this or any other type of stele ${ }^{1}$. It is difficult to find a suitable word to express the idea of scattered vascular strands as typically found in Monocotyledons. As indicating irregular arrangement, atactostele may serve for this type, whether the individual bundles lack or possess a cambium. An atactostele therefore consists of a number of more or less irregularly arranged vascular bundles together with the ground tissue in which they are imbedded. It is now known that a large number of Dicotyledonous plants have scattered vascular bundles, and, as already indicated, they would be said to be atactostelic. In certain of them the vascular bundles are all of one type, and the stele in that case would be said to be homodesmic. In other cases, however, there are 'medullary' strands which consist of phloem only (e.g. in Gentianaceae and Melastomaceae), and then the steles might be called heterodesmic. Cucurbita may be taken as an example of atactostely among the Dicotyledons and Habenaria bifida of eustely among Monocotyledons. The term solenostele as defined by Gwynne-Vaughan ${ }^{2}$ will be retained for the continuous amphiphloic tube with widely separated leaf-gaps ${ }^{3}$. Another and closely allied type of 'siphonostele ${ }^{4}$ ', in which a tubular network of vascular tissue results from the overlapping of the leaf-gaps, seems well described by the term dictyostele. This is a common condition found in Ferns, and well illustrated by the vascular system of Aspidium, with

\footnotetext{
${ }^{1}$ It would perhaps be better to fix the phloem as the outermost limit of the stele on account of the want of constancy in origin of the 'pericycle,' but in the meantime, at any rate, the other definition is adopted.

${ }^{2}$ Gwynne-Vaughan, Observations on the Anatomy of Solenostelic Ferns, Annals of Botany, xv, p. 73, I90r.

${ }^{3}$ Neglecting the internal endodermis as a morphological criterion, it might be well to include it and the rest of the central parenchyma in the definition of the solenostele, but at present Van Tieghem's term, as revived and defined by GwynneVaughan, will be retained.

${ }^{4}$ Jeffrey applies this term to the eustele of Dicotyledons and the solenostele of certain Vascular Cryptogams and also to the network-like stele of others.
} 
which all are familiar. The word would apply whether the dictyostele were tubular as a whole (Bündel-Rohr of De Bary), as in Aspidium, or consisted of an irregular compound network of anastomozing strands as in Pteris aquilina and Angiopteris evecta. Jeffrey ${ }^{1}$ has proposed the term adelosiphonic to describe the 'siphonostelic central cylinder' when it 'ceases to be obviously tubular.' Adopting his terms, the clearly tubular dictyostele would then be described as siphonic and the more irregularly constructed form as adelosiphonic.

In certain cases the central cylinder seems to be clearly reduced, or modified, as a result of habitat, e.g. in Hottonia, aquatic stem, and in Potamogetons, \&c. The term hysterostele would distinguish these forms satisfactorily. Having thus named and described the chief types of stele, the question remains to be considered how to speak of the individual strands of any of those steles. The term meristele would seem to answer, but modified from its original meaning as used by Van Tieghem and Strasburger. A sense in which it has been used and in which it is proposed to be used here is due to Jeffrey, who applies the word to the individual strands of any vascular system. The application of the term will not be confined to the vascular strands of the stele only, but will be extended to those of the outgoing leaf-traces and their continuation into the leaves. This is done purely as a matter of convenience, on account of the apparent identity in structure, in most cases, of those strands, not on account of any theoretical considerations as to how the leaf bundles become continuous with those of the stem or vice versa. The terms collateral, bicollateral and concentric, can be just as well applied to the same types as under the old vascular bundle terminology, with this gain that haplosteles and actinosteles are not included. The 'steles,' or now meristeles, of some of the 'polystelic' Primulas and Gunneras are reduced eusteles in structure, and if desired could be simply described as eumeristelic, and those of the simple fern-

1 E. C. Jeffrey, The Structure and Development of the Stem in the Pteridophyta and Gymnosperms, Phil. Trans. Royal Society, vol. cxcv, 1902, p. I44. 
type as haplomeristelic. In speaking of outgoing leaf-traces the prefixes mono, di, tri, \&c. could be used, to simplify description. The use of meristele in the ways suggested is illustrated by a description of the behaviour of the outgoing leaf-traces in Danaea simplicifolia: e.g. in the very young seedlings the outgoing leaf-trace-meristeles are collateral, but the later-formed ones are concentric, just like the dictyomeristeles. The leaf-traces themselves are at first monomeristelic throughout their course, then dimeristelic through dichotomy, subsequently they are dimeristelic from the first, then they are trimeristelic, and finally in the most advanced seedlings examined they were found to be tetrameristelic.

The aim in suggesting, and adopting, the above modifications in and additions to the stelar terminology was to get words which had as little as possible of theoretical connotation, and were at the same time fairly descriptive and clearly defined. Complete avoidance of theoretical connotation is of course impossible, nor is it always desirable. Time, which tests all things, will show if this attempt to simplify stelar terminology by increasing the number of terms was a wise one.

\section{SYNOPSIS OF TERMS.}

Eustele. The 'monostele' of a typical Dicotyledonous plant. It consists of a ring of collateral or bicollateral meristeles, and includes the pericyclic and medullary ground tissue.

Actinostele. The 'monostele' of most roots and the similarly constructed stele of certain stems. It consists of alternating, or ' radially' arranged groups of xylem and phloem, surrounded by a pericycle. Pith may or may not be present.

Atactostele. The monostele of typical Monocotyledons. It consists of a number of scattered vascular bundles imbedded in conjunctive ground-tissue. Also applied to the stele of Dicotyledons with meristeles not arranged in a single ring. In the latter, if the meristeles are all of one kind, described further as homodesmic, if of different kinds, as heterodesmic. 
Haplostele. A simple type of stele, frequently found in seedling Pteridophyta, rhizome of Hymenophyllaceae, \&c. It consists of an axial rod of tracheae surrounded by a ring of phloem. The 'pericycle' is included if differentiated from the procambium-strand. If central parenchyma is present, then to be described as a medullated haplostele.

'Solenostele.' A continuous amphiphloic tube of vascular tissue with widely separated leaf-gaps. Pericycle present and the tube delimited by an external and internal endodermis.

Dictyostele. A vascular tube with large 'overlapping' leaf-gaps, so that the whole structure becomes a network of vascular strands or meristeles. The meristeles are concentric. This is closely allied to the preceding, the difference being due to the approximation and overlapping of the leaf-gaps. The dictyostele is further defined as siphonic when the network is simple and tubular, adelosiphonic when complex, i. e. ceasing to be obviously tubular.

'Protostele.' A stele which is supposed to be primitive in structure. Has been applied to both haplo- and actinostelic types.

Hysterostele. A stele which is supposed to be reduced in structure, e. g. in Hippuris, Potamogeton and Hottonia (aquatic stem).

Moristele. The vascular bundle in the old sense, except that it does not include actino- and haplosteles as formerly. It therefore applies to the vascular bundles of the stem of Dicotyledons and Monocotyledons, the 'concentric vascular bundles' of Pteridophyta, and vascular bundles of outgoing leaf-traces and leaves.

\section{Development of the Vascular System of DANAEA SIMPLICIFOLIA.}

A number of seedling plants of various ages were available, and these were examined chiefly by means of microtome serial sections. The sections were usually doubly stained with haematoxylin and safranine and mounted in Canada balsam. The advantage of this method of staining, when 
successfully carried out, is that the endodermis shows up well, being distinctly stained red, thus contrasting with the dark purplish-blue of the cellulose-walls of the groundtissue and phloem. In cases where sieve-tubes were required to be distinguished, dilute glycerine $\left(5^{\circ}-70\right.$ per cent. glyc.) and safranine, or glycerine jelly and safranine were used.

Beginning at the base of a very young seedling, or older one if the base is not decayed, the vascular axis of the stem is found to consist of a haplostele ${ }^{1}$. The mode of transition from the diarch actinostele of the root to the haplostele of the stem was described in a paper on the prothallus and embryo of Danaea simplicifolia, Rudge ${ }^{2}$, and agrees in every essential respect with the state of matters found by Farmer and Hill in Angiopteris. With regard to the first and earlier roots of Danaea, the protoxylem not infrequently abuts directly on the endodermis, or is separated from it by one pericyclic cell either at one or both ends of the diarch xylem-plate, but in this it does not show any essential difference from many other roots. The following quotation from Farmer and Hill's paper ${ }^{3}$ might have been written for Danaea simplicifolia:'The diarch xylem-plate of the root loses its definite outline owing to a considerable increase in the number of its tracheids that appear at the sides of the plate, which causes the wood to be roughly circular in transverse section; at the same time the protoxylem loses its individuality and the diarch character becomes entirely lost. The phloem also extends over the periphery of the wood.' In Danaea, as in all the Marattiaceae, the sieve-tubes are distinguished by their relatively thick and glistening walls, and by the proteid-granules applied to their pitted areas. The sieve-tubes, however, often do not show up well in Canada balsam preparations, although the phloem as a whole is nearly always readily distinguishable. In seedlings they are very small, compared to the size they attain in the older plants, but are of the usual Marattiaceous type. In Danaea seedlings, unlike Angiopteris, the pericycle ${ }^{4}$

1 See definition in Introduction.

3 Loc. cit., p. $3^{84}$.

2 Loc. cit.

${ }^{4}$ Cf. Farmer and Hill, loc. cit., p. $3^{8}$. 
is frequently not a well-marked tissue (cf. Fig. 9, Pl. XXII). It may even be represented by an isolated cell or two ${ }^{1}$, the endodermis abutting directly on the phloem. If, as seems to be the case, the so-called pericycle consists of sister-cells of the endodermis, then it is not a pericycle by the definition that makes that layer the outermost one of the stele. Not infrequently the inner of the two sister-cells has cuticularized radial walls as well as the outer. In one or two cases undoubted phloem-parenchyma cells likewise had cuticularized cell-walls. On that account it would seem that there is very little constancy in the position of the histologically differentiated endodermal cells. In the seedlings of Danaea simplicifolia, however, the endodermis is on the whole a wellmarked layer, and, as a matter of convenience, it will be treated as the boundary-layer between the stele or meristeles and the rest of the extrastelar tissue. At the next stage to the constitution of the haplostele there seems to be a distinct difference between Danaea simplicifolia and Angiopteris. The observations of Leclerc du Sablon are confirmed by Farmer and Hill with regard to the appearance of parenchyma in the centre of the xylem of the haplostele, which increases in amount till what they call a pith is present. In Danaea there is no such distinct pith differentiated, and the very small amount of parenchyma which does appear is clearly to separate the xylem of the outgoing leaf-trace from that of the haplostele (Plate XXII, Figs. I-3). The earlier leaftraces are usually separated off before the first lateral root joins the stele, tracing from below upwards ${ }^{2}$, consequently

1 Cf. Fig. 20, prothallus of Danaea, \&c., loc. cit.

${ }^{2}$ In all cases the development is described from below upwards, and hence the roots will be spoken of as coming in to the stele, but at the same time it has to be clearly borne in mind that the roots arise from the endodermis (this has not yet been definitely proved) and pass outwards and downwards. It is also important to remember that there is a large area of junction between the stele of the root and that of the stem, and that the root-junction very considerably affects the structure of the xylem not only in the immediate neighbourhood of the anastomosis, but for a considerable distance upwards and downwards. The texture of the xylem is much looser on account of the presence of a considerably greater amount of parenchyma. 
matters are not complicated so early by the influence of the root as is the case in Angiopteris, which gives off a root nearly opposite the first leaf-trace ${ }^{1}$. The parenchyma marked $p$. in Fig. I3, Pl. XVI (Farmer and Hill, loc. cit.), and called pith, is probably simply due to the root-junction and preparation for the departure of the leaf-trace. In Danaea simplicifolia, then, the xylem of the first leaf, or cotyledon-trace, is marked off from that of the haplostele by a layer of parenchyma, and this increases in amount till the leaf-trace becomes free. The leaf-trace is collateral, and phloem appears on the side of the haplostele facing the departing trace-meristele, and thus becomes repaired or restored. This repairing phloem, at higher levels, sometimes makes its appearance in the intrastelar parenchyma before the leaf-trace becomes free, and might be interpreted as phloem appearing in pith. This process of giving off a leaf-trace with restoration of the haplostele is repeated several times, varying in number with the seedling and more or less affected by the junction of roots with the haplostele ${ }^{2}$. This is, therefore, nothing more nor less than the usual mode of departure of a leaf-trace from a simple rod-like stele, i. e. haplostele. Although, in the early stages of development of the vascular system, the successive departure of leaf-traces with resumption of the haplostelic condition seems to be the rule, one seedling showed a striking variation. It had in all six leaf-traces fully differentiated. Instead, however, of the usual mode of behaviour, the xylem soon showed parenchyma among the tracheids, which was at first irregularly distributed, but later occupied a central position (cf. Fig. 6). The appearance at this stage somewhat resembles the state of matters figured by Leclerc du Sablon for Angiopteris ${ }^{3}$, and the central parenchyma might be called a pith. The unusual condition was due to abortion of the cotyledon-trace, and preparation

\footnotetext{
1 Farmer and Hill, loc. cit., p. 376.

2 In this there seems to be no essential difference from what happens in Angiopteris (Farmer and Hill, loc. cit., p. $3^{8} 5$ ) except for the presence of a pith in the latter.

3 Loc. cit.
} 
for the almost simultaneous departure of the next three leaf-traces. At a higher level the whole thing has resolved itself into a state of matters such as shown in Fig. 5, with the difference that there are three outgoing leaf-traces instead of two. The remaining leaf-traces were given off in the usual way, and there was only one cauline root. This seedling is mentioned on account of its apparent pith, but it is so abnormal that much importance cannot be attached to it. It is interesting to note that sieve-tubes, \&c. appear in the central parenchyma. As already mentioned, the earlier leaf-trace meristeles are collateral, but those developed later are concentric, hence according to Van Tieghem's terminology, the former would not be 'steles' and the latter would. With regard to the leaf-traces themselves, the earlier ones are monomeristelic ${ }^{1}$ and collateral; later they become concentric. The next step is that the xylem becomes separated into two masses as the leaf-trace passes out, but without actual dichotomy. Later, i. e. at a higher level, the originally single meristeles dichotomize, and finally they are given off separately $a b$ initio. To take a concrete example:-One of the seedlings microtomed had thirteen leaves and therefore leaftraces. The first six outgoing leaf-traces were monomeristelic and monoxylic, the seventh was at first monoxylic and became dixylic. The eighth was monomeristelic and then became dimeristelic through dichotomy. The ninth behaved much as the eighth, the tenth was dimeristelic from the start. The meristeles of the tenth leaf-trace, when they reached the leafbase, each gave off a strand to the stipules, which were now distinctly developed. The eleventh, twelfth and thirteenth leaf-traces behaved as the tenth.

The following is a short account of the general sequence of events in the formation of the dictyostele from the haplostele. First of all, there is the haplostele with a solid core of tracheids, this becomes somewhat oval in outline, a layer of parenchyma divides the xylem into two more or less equal halves; this parenchyma increases in amount till it

\footnotetext{
${ }^{1}$ See Introduction, p. $5^{22}$.
} 
extends right across the stele and the cotyledon-trace is cut off. The phloem reappears on the side of the haplostele facing the leaf-trace, and the endodermis is differentiated in the ground-tissue between the two ${ }^{1}$. This process is repeated a variable number of times, the haplostele showing a fluctuating tendency to become crescentic, especially about the place of junction of a root. When the stele does become definitely crescentic, it is not due to the departure of a 'sector' from a medullated haplostele, but because it is laid down in that shape by the differentiating meristem, hence there is no leaf-gap, in the ordinary sense, at first. After this crescentic stage has been reached, the next leaf-trace may go off from the convex side of the crescent (Fig. 28, diagram I), leaving two meristeles behind with a portion of extrastelar ground-tissue between them. The space ${ }^{2}$ facing the previous leaf-trace is closed (diagram II) at the time a root comes in, and another leaf-trace is soon given off (diagram III). Thus the beginnings of the dictyostele are laid down, and it practically amounts to the branching of the haplostele through the formation of leaf-gaps. Up to this stage the leaf-trace is monomeristelic, only becoming dimeristelic through late dichotomy, but succeeding traces soon become dimeristelic from the first. Diagrams V, VI, VII, show how this takes place. After the crescent has been restored by the closing of the leaf-gap, the root $\mathrm{R}$, coming in as usual, a portion is again separated off $\left(m^{\prime}\right.$, diagram $\left.\mathrm{V}\right)$, and rejoins the opposite horn of the horseshoe at a higher level $\left(m^{\prime}\right.$, diagram VIII). From each of the tips of the crescent or horseshoe a leaf-trace meristele is now separated off, and the leaf-trace is dimeristelic from the beginning (diagram VIII, l.t.). Once this stage has been reached, or earlier in some cases, the central

1 In the Figs. I, 2, 3, Pl. XXII, the endodermis is not represented round the leaf-trace meristele, because the preparation did not show it, either through defective staining or because the seedling was too young. It was quite clearly seen in other cases, however, e. g. Fig. 7 .

2 This space, i. e. on the right of the diagram, is not a leaf-gap, but due to the change from a haplostele to a crescentic one, subsequently to the departure of the leaf-trace. 
strand (Centralstrang ${ }^{1}$, commissural strand ${ }^{2}$ ) makes its appearance as a branch from the inner face of the more or less crescentic meristele, diagram IX, c.s. (cf. E. C. Jeffrey, Phil. Trans. B. Vol. cxcv, Pl. I, phots. 4 and 5). It traverses the groundtissue, passing obliquely upwards (diagram $\mathrm{X}$ ), joins the stelartissue of the opposite side usually at the same time as an incoming root (diagram XI). The leaf-gap is now closed, and there is what might be called a transitory solenostelic condition ${ }^{3}$. In Danaea this amphiphloic ring, with external and internal endodermis, has been found in all the seedlings which were old enough to have it, but it does not seem to occur at the corresponding level in each, nor is it so clearly developed in all. In most cases, moreover, there is a suggestion of an abortive attempt at its formation at a lower level. The central strand also may make an abortive attempt at formation, as in one seedling it was found to consist of phloem only. Farmer and $\mathrm{Hill}^{4}$ found exactly parallel conditions in Angiopteris. From the point of view of development it is important to note that the central parenchyma, with or without a mucilage-canal, is extrastelar in origin, and not continuous with any parenchyma formed within the haplostele as a pith. In this, Danaea simplicifolia differs both from Angiopteris and Aneimia phyllitidis ${ }^{5}$. A study of the microtome-series shows the mode of development clearly. As has

${ }^{1}$ R. Kühn, Untersuchungen über die Anatomie der Marattiaceen und anderer Gefässkryptogamen, Flora, 1889, p. 463 .

2 Farmer and Hill, loc. cit., p. 376, par. 3 .

${ }^{3}$ Fig. 3, Farmer and Hill, loc. cit., illustrates a distinct solenostelic stage in Angiopteris, for the leaf-gaps do not over-lap. It is impossible to decide from the text whether the tube is amphiphloic or not. In the latter case it would be what these writers call pseudosolenostelic.

${ }^{4}$ Loc. cit., p. 387 , par. I.

5 L. A. Boodle, Annals of Botany, xiv, p. 389. After all, it may be only a difference in degree, through the reduction or loss of the central parenchyma in the case of Danaea simplicifolia, which is a very small plant compared to Angiopteris, in its seedling as well as in its adult condition. It might also be that it is Danaea, which is the more primitive, and that the parenchyma, which in the first instance appeared simply to cut off the leaf-trace, grew to be a 'pith' for conducting and storing purposes as plants advanced in complexity and size. The writer does not feel competent to express any opinion as to which of these two views is the more rational. 


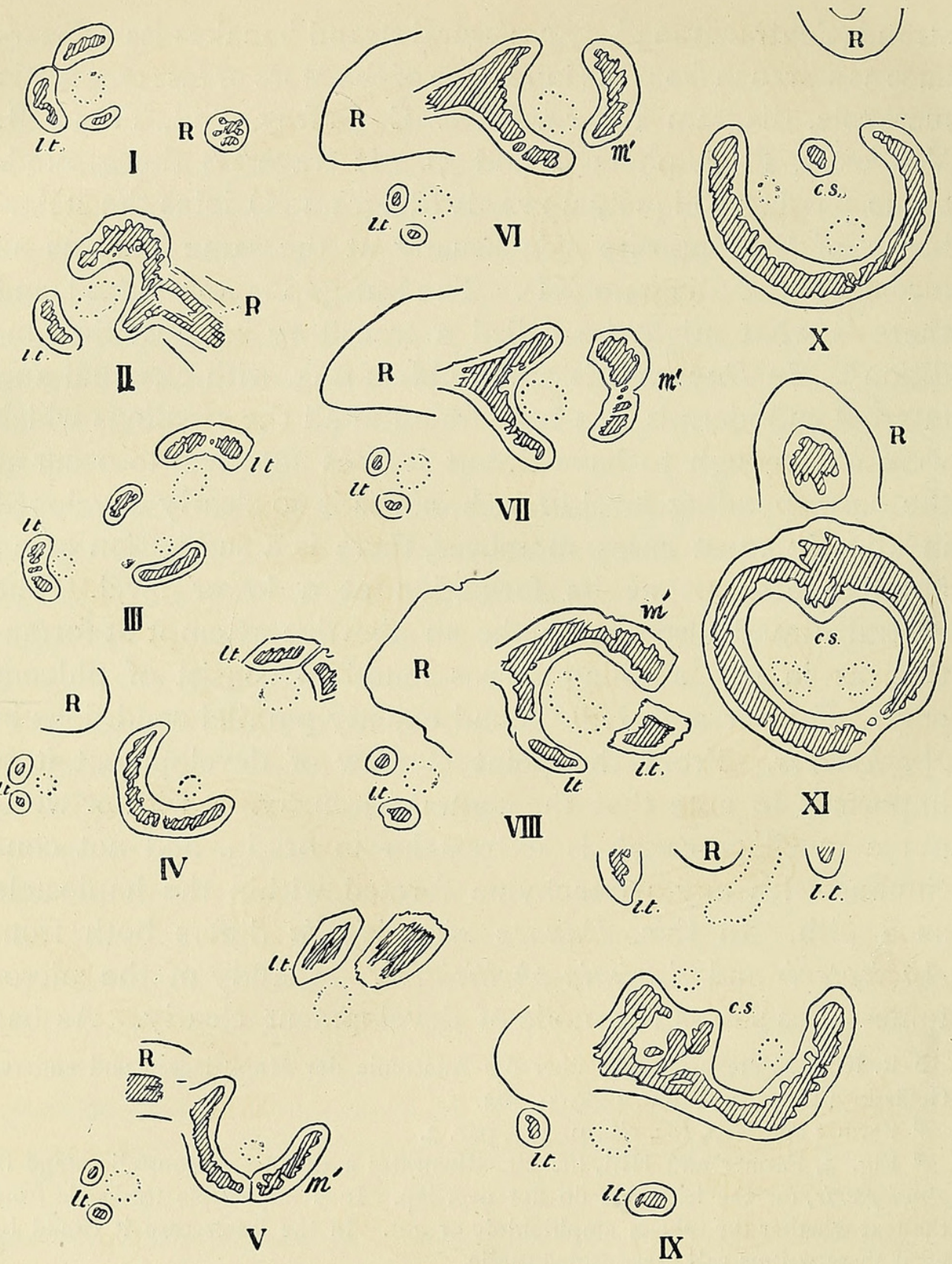

FIG. 28.

FIG. 28. The diagrams illustrate horizontal sections of a hand-cut series of a seedling stem of Danaea simplicifolia at successively higher levels.

Diagrams I to VIII are in fairly close sequence, but not consecutive.

Diagrams IX to XI are in sequence after a considerable gap between VIII and IX.

FIG. 29. Sections from the same series as Fig. 28. Diagrams XII and XIII are near each other ; XIV is isolated; XV-XIX are in sequence, but not consecutive.

Smooth contours mark outer limit of phloem. Shaded parts indicate xylem. Dotted contours indicate mucilage canals.

Abbreviations in Figs. 28 and 29 : c.s. central strand or commissure or a branch from it ; $c^{\prime} . s^{\prime}$., branch of central strand; $K . \sigma$. original commissure after giving off 

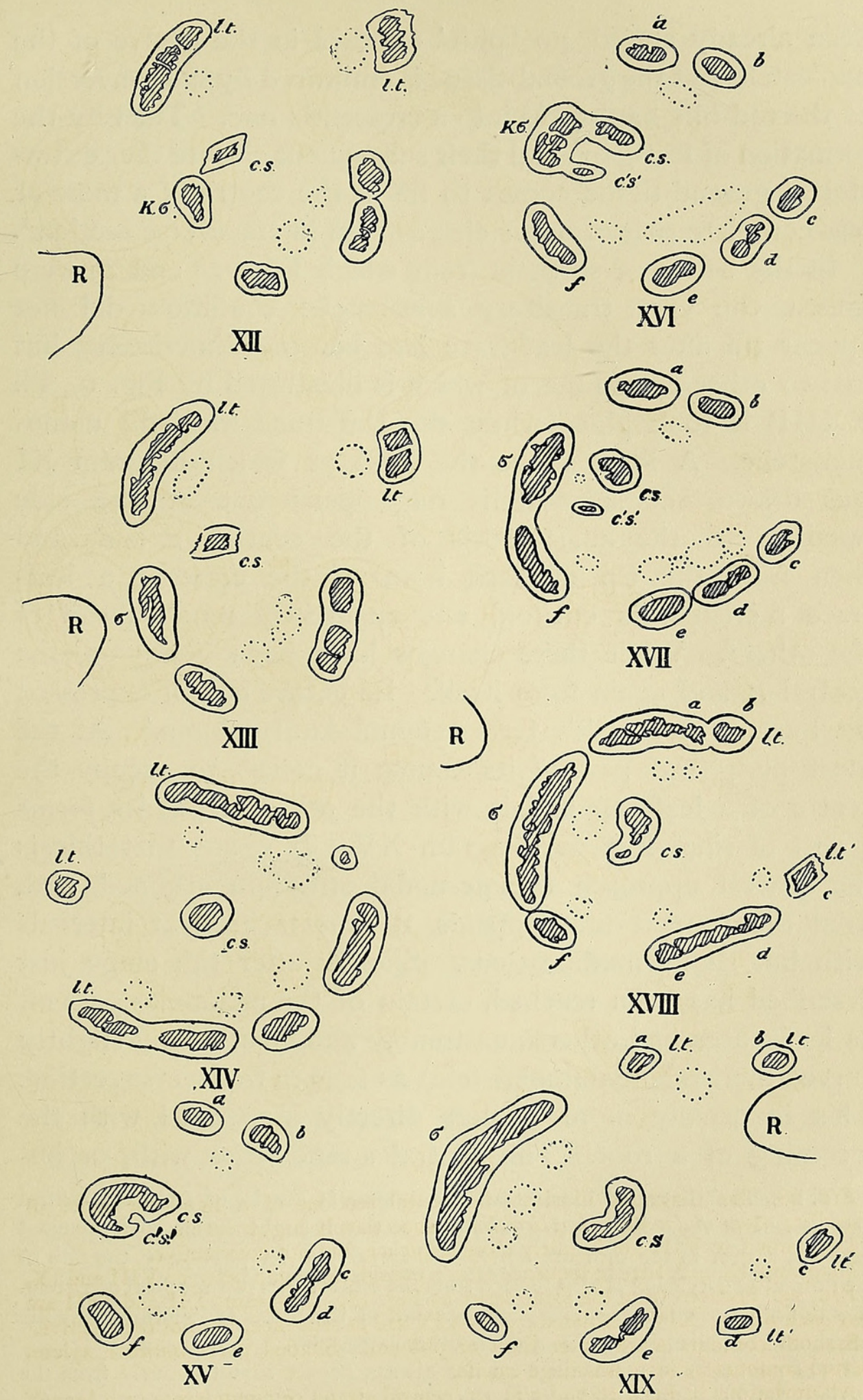

FIG. 29.

branch ; $\sigma$. meristele which is upward continuation of $K . \sigma . ;$ l.t. and l.t.' leaf-trace meristeles; $m$. ' meristele of stem; R. root; a. b.c. d. e. f. meristeles which sooner or later pass out as leaf-traces. 
been already stated, no 'pith' appears in the centre of the haplostele, but the ground-tissue is embraced by the conversion of the rod-like haplostele into a crescentic one. Then by the formation of leaf-gaps and their subsequent closure the 'extrastelar' ground-tissue comes to lie in the centre of a more or less complete ring of meristeles, as seen in transverse section ${ }^{1}$.

In the series of sections from which Figs. 28 and 29 were drawn, the very transitory solenostelic condition did not appear till after the leaf-trace had become dimeristelic, but in two other cases (one of which is illustrated by Fig. I9, Pl. XXIII) it took place while the leaf-trace was still monomeristelic. A little above the level at which diagram XI was drawn, the solenostelic ring opens out at the side opposite to the anastomosis of the central strand, and then from the tip of each horn of the crescent a leaftrace meristele is cut off, one apparently much ahead of the other ${ }^{2}$. While these changes have been going on, the central strand again frees itself. Its nature is well expressed by Farmer and Hill's term 'commissural column.' At the most peripheral part of its course it comes to occupy the centre of a leaf-gap, and it, with the other meristeles, forms a sort of ring, Fig. 29, diagram XV. It seems that this is the nearest approach to internodal structure attained, and, from the time it first appears, it repeats itself at intervals with but slight modifications. Shortly after the stage just described has been reached, certain of the meristeles pass off as leaf-traces and others anastomose and form a long slightly curved meristele (gamomeristele), as seen in transverse section. This is usually more or less directly associated with the incoming of a root. The central strand fuses with, or be-

1 This central, so-called extrastelar, parenchyma is developed from the central parenchyma of the differentiating meristem, so that it might not be so far-fetched to call it a pith in the ordinary sense. Whatever was its phylogeny, the pith of the normal Dicotyledon is also formed from the central part of the apical meristem. It is difficult to understand, except on account of the fetish endodermis, why the one should be called intrastelar and the other extrastelar.

2 The meristeles of a leaf-trace do not always depart simultaneously from the dictyostele; but a little obliquity in the plane of section, which is often unavoidable, considerably emphasizes the discrepancy. 
comes merged in, this curved plate of tissue (for such it is in reality), only to be again given off higher up. The next commissural branch may, however, be given off before the previous one is merged in the curved plate, Fig. 29, diagram XII, K. $\sigma$., central strand, c.s., new commissural branch. In the next diagram $\sigma$. is the upward continuation of K. $\sigma$., and at a slightly higher level it will anastomose with the meristeles on each side of it and the incoming root, $\mathrm{R}$. In these two diagrams the small meristele, l.t., is one of a leaf-trace pair, the other will be given off from the long meristele opposite at the end marked l.t. The next diagram, XIV, shows the formation of a trimeristelic leaf-trace referred to above. The small strand, l.t., became free at a considerably lower level, and the two remaining strands of the trace will be given off from the large meristeles marked l.t. at their outer ends. This trimeristelic leaf-trace was formed twice, before the tetrameristelic condition was attained in this seedling. Diagrams XV-XIX show a further modification in the behaviour of the central strand, and the formation of a tetrameristelic leaf-trace. In this case the central strand, after it reaches its peripheral position in the centre of the leaf-gap, gives rise to two branches, c.s. and c.'s.' These branches unite at a higher level, and the central strand is restored (diagrams XVIII, XIX). This state of matters was found in two different seedlings. Diagrams XV to XIX are not consecutive sections, but are in sequence, and show a typical and frequently recurring state of matters. Diagram XV illustrates the nearest approach to internodal structure met with, and already referred to. Diagram XVI shows the maximum number of meristeles present at this phase, $a-f$. The strands $a, b, c, d$, will become leaf-trace meristeles. They, however, do not leave the dictyostele without first anastomozing and again separating before passing outwards as the leaf-trace meristeles, as seen in the succeeding diagrams. In Diagram XIX the four leaf-trace meristeles have now definitely left the dictyostele, and the two branches of the central strand have completed their fusion. The meristeles, $e$. and $f$., together with branches from $\sigma$ will give O 02 
rise to the next leaf-trace, which also consists of four meristeles. The meristeles, $e$. $f$., in their turn, behave as $a . b$. did at the lower level. After this stage is reached there is little further complexity attained as far as the oldest seedlings available showed. Judging from the adult rhizome of D. alata, such changes as do occur are due to an increase in the number of the leaf-trace meristeles and the tendency of the meristeles generally to branch and anastomose, as is so strikingly illustrated in the case of Angiopteris.

In this way, then, the somewhat irregular or adelosiphonic dictyostele of Danaea is established, viz. by a process which is, to all intents and purposes, a branching of a haplostele, due to the departure of the leaf-traces of closely set, spirally arranged leaves. The complications which arise are due to a tendency of the meristeles themselves to branch, to the formation of a central commissural column, and to the presence of an abundance of cauline roots.

It will be appropriate to note here a few remaining points of interest in the anatomy of these seedlings. It was mentioned that the central strand sometimes begins as a phloem-commissure only. It is therefore not surprising to find meristeles losing their xylem and continuing their course as phloem-strands, till they rejoin the system at a higher level. Farmer and Hill found that the central commissures sometimes ended blindly in their upward course. That was not observed in Danaea, but the time and manner of its branching varies a good deal. For instance in the seedling from which Figs. 28 and 29 were drawn, at a stage subsequent to that of the double branch shown in Diagrams $\mathrm{XV}$-XVII, first one branch was given off, and then another followed, the latter anastomozing with the former on the way upwards and across. In the oldest seedling cut, not more than two commissural branches were given off at any level, and the later ones only differ from those figured in their greater size and importance.

The root (R. in Figs. 28 and 29) behaves in a fairly constant manner. When the leaf-trace is paired, it generally, though 
not always, comes in medianly, and there is frequently one root for each leaf. Its fusion ${ }^{1}$ with the dictyostele is usually associated with the closing of a leaf-gap, and synchronizes with the junction of the central commissure with the dictyostele $^{2}$. The meristeles, whether of the dictyostele, the outgoing leaf-traces, or the fronds, are all built very much upon the same plan, viz. the usual Marattiaceous type. The phloem of the seedlings is so narrow in the radial direction, that it is practically impossible to distinguish proto-from a later formed phloem, as can be done in the case of older and adult plants. The protoxylem in the leaf and leaf-trace meristeles is endarch, as usual for the family, and more or less clearly mesarch in the dictyomeristeles. There is very little sign of what Farmer and Hill call secondary thickening, or of secondary merismatic division of the ground-parenchyma, except as a result of injury or undue pressure. The Marattiaceae generally have a great tendency to form what seems to be wound-periderm, but more will be said of this when dealing with the comparative anatomy. A small peculiarity that might be noticed en passant is the occurrence of an isolated tracheid in the ground-tissue in a leaf-base. It is of no great importance except in helping to show that the line to be drawn between stelar and extrastelar tissue is not a hard and fast one. This question will be dealt with under the heading 'Review of Terminology in Relation to Morphology.'

The study of the transverse sections of the seedlings of Danaea simplicifolia inevitably leads to a belief in the importance of the central strand or 'sympodial commissural column.' It is undoubtedly the one part of the dictyostele which is purely cauline. If the parts of it, where it is continuous with the other meristeles, be included, it may be said to follow a somewhat zigzag spiral course, because its points of junction move through the same angle which is described

1 It has constantly to be borne in mind that this is only a descriptive façon de parler.

2 If one were to imagine a transverse section across Fig. 4 (Farmer and Hill, loc. cit.) at the level of the lettering $r t .3$, one would have a very good idea of the state of matters in $D$. simplicifolia as described, but generally the root is more median, and opposite the commissure. 
by the leaf-spiral, roughly $144^{\circ}$. As the roots in nearly all cases join the dictyostele at or near the most peripheral position of the central strand, they are pretty obviously attached to the stem meristeles, as distinguished from the outgoing leaf-trace meristeles. This brings Danaea into line with the observations of Lachmann ${ }^{1}$ on the behaviour of the roots of Ferns generally. As the result of a very careful and extensive piece of work, he came to the conclusion that the roots of Ferns were developed from the stem (stele ?) not the leaves (outgoing leaf-trace meristeles?). The only case in which he found a direct connexion of the root with petiolar meristeles was that of Ceratopteris thalictroides ${ }^{2}$.

The physiological meaning of the central strand is pretty obvious. As has been seen, it directly connects the rootbearing gamomeristeles at one level with the corresponding part at the next higher level, and so on. As the leaf-traces are given off from these curved plate-like masses, it is obvious that a considerable portion of the water absorbed can do what corresponds to 'short circuiting' in electrical terminology. But that is probably not all, for the roots, which are thus developed in close relation to the leaf-traces, probably do not reach the soil till some time after the related leaf has unfolded, hence the special advantage of such a central strand or commissural column is obvious. Finally the central strand also behaves as a reparatory strand ('Ersatzstrang') helping to close the leaf-gap.

\section{Comparative Anatomy of the Marattiaceae. The Frond.}

The anatomy of the frond of the following species of Marattiaceae was examined and compared:-

Angiopteris evecta, Hoffm. M. alata, Smith.

Marattia fraxinea, Smith. Danaea simplicifolia, Rudge.

1 J. Paul Lachmann, Contribution à l'histoire naturelle de la Racine des Fougères. $8^{\circ}$, 199 pp., 5 pl., Lyon, I 889.

${ }^{2}$ Cf. text, fig. I. S. O. Ford, The Anatomy of Ceratopteris thalictroides, Ann. of Bot., xvi, 1902 . 
M. cicutaefolia, Kaulf. Danaea alata, Smith.

M. Kaulfussii, J. Sm.

M. Laxa, Kze.

Danaea elliptica, Smith.

Kaulfussia aesculifolia, Blume.

Sections were made from them at all the important levels, as far as the material permitted. As is well known, the fronds of the Marattiaceae have a broad leaf-base with large stipules. From the top of the leaf-base springs the pulvinus, which then tapers into the rest of the petiole ${ }^{1}$.

Secondary and tertiary pulvini are found at the bases of the secondary and tertiary axes. In some cases the leaflets of the pinnules are practically sessile, but even then the base of the midrib is swollen. A pulvinoid swelling is sometimes present above the insertion of the lateral axes. This is of some slight importance, because occasionally in Angiopteris and Marattia, and frequently in Danaea, there are pulvinoid swellings or 'nodes' on the petiole. In the lastnamed genus there are often quite a number of these nodes normally present in some of the species. These swellings have been interpreted, apparently with good reason, as representing the position of lost pinnae. The internal structure of these ' nodes' is practically identical with that of a basal pulvinus.

Miss Shove (loc. cit.) has illustrated the structure and arrangement of the meristeles of the leaf-base and stipules of Angiopteris. There is no important difference in Marattia, or in the new genus Archangiopteris, so far as observed. Most of the fronds had been cut just below the pulvinus, so that the leaf-base was wanting, but the whole of a fair-sized plant of $M$. alata (reared from a stipule) was available. In this species there is a very distinct and considerable narrowing of the leaf-base at its insertion, and there is no reason to suppose that this feature is exceptional. Careful examination of the leaf-base showed no sign of a stipular commissure, which is, however, stated to be present by Kühn. His

\footnotetext{
1 The fronds of the Marattiaceae are too well known to require general description here, so only those parts will be specially mentioned which are concerned with anatomical features to be described. For the diagnoses of the various species the reader is referred to the 'Synopsis Filicum,' Hooker and Baker.
} 
description leaves some doubt about the matter, and it is possible that the absence of a stipular commissure may be a generic difference. Archangiopteris, Angiopteris and Danaea have distinct, not to say well-marked, commissures. Kaulfussia was not examined for this feature. In Marattia alata only a very few, three or four, meristeles pass into the leaf-base from the stem, but they then branch very freely, so that they become very numerous. They are not very definitely arranged in the leaf-base, but, by the time they have reached the pulvinus, they have taken up a definite and characteristic position. In the case of a frond of Marattia alata, about three and a half feet long, three or four meristeles passed into the leaf-base; there they branched freely, giving rise to $33-34$ meristeles, as seen in transverse section of its middle region. In the middle region of the pulvinus there were likewise 34 meristeles. Their arrangement in the pulvinus and petiole is illustrated by Figs. I I and I2 (P1. XXII) from $M$. fraxinea, which is a much smaller plant than $M$. alata, and therefore there are correspondingly fewer meristeles. The arrangement is essentially the same in all the species of Marattia examined. In this genus, as also in Angiopteris and Danaea, the meristeles ( $m s$. in the figures) form a ring, somewhat flattened towards the upper surface, and besides there is a sort of indentation formed by a single, or a few, meristeles (ms.'). In all these vascular strands the protoxylem is directed towards the centre. Then further there is a small number of meristeles (ms.") nearer the middle of the pulvinus, or petiole, in which the protoxylem faces upwards, or outwards towards the ring. As already said, there is the same general arrangement in all the Marattiaceae, but in Angiopteris there are several almost concentric sets of meristeles. In a petiole of Angiopteris, $\frac{5}{8}$ in. thick, there were three such sets. The possession of more than one set of concentrically arranged meristeles in the petiole seems to be generically distinctive of Angiopteris. It may be that, in the full-sized fronds of the larger species of Marattia, the same thing may be found, but in the absence of the 
necessary material it could not be decided. There is nothing peculiar about the meristeles themselves in this region. They are comparatively small and anastomose at not very frequent intervals. Figs. II and 12, Pl. XXII, are from the primary axis ; Fig. 13 is just below the first pair of pinnae ; Figs. I5I7 represent the pulvinus and rachis of one of these pinnae, and Fig. I 4 the pulvinus of the other. In the last named there is a gamomeristelic ring, which in its structure recalls the solenostelic stage of the Danaea-seedling, or the solenostele of Marsilia. In the leaf, however, there is no external nor internal endodermis. The absence of mucilage canals in Figs. 14 and 15 shows that these structures are not continuous from the primary to the secondary and succeeding axes.

As is well known, the collenchyma of the pulvinus passes into the pale yellowish (sometimes even faintly brownish) sclerenchyma of the rest of the petiole and the rachis ${ }^{1}$.

In the leaf the mucilage-canals do not seem to have any very definite arrangement. They generally pursue a fairly continuous longitudinal course, sometimes branching and forming an occasional horizontal anastomosis. They sometimes also end blindly. Tannin-sacs are abundant and are usually arranged round the meristeles. The black dots in Figs. I 2, I3, I5, 16, I7 represent the tannin-sacs.

One of the chief objects of the investigation was to ascertain if there were any anatomical features which by their form, position, variation in presence or absence, afforded means of generic or specific distinction. It has already been pointed out that the arrangement of the petiolar meristeles of the older fronds of Angiopteris distinguishes it from the other genera. In addition it was found that to a certain extent (I) the sclerenchyma, (2) the mucilage-canals, and, in a less degree, (3) the tannin sacs yielded means of anatomical, specific or generic distinction.

${ }^{1}$ It may be as well here to again emphasize the fact that the sclerenchyma in Danaea is of the usual Marattiaceous type, and not brown like that of the leptosporangiate Ferns. This was verified in the fronds of three different species, and the rhizome and roots of Danaea alata. Cf. Kühn, Ueber den anatomischen Bau von Danaea, Flora, 1890. 
(I) The sclerenchyma. The petiolar sclerenchyma in most of the Marattiaceae is a simple continuous band of thickwalled elements a little below the epidermis, Fig. I3, scl., but in Angiopteris its inner margin is sculptured owing to circular groups of the sclerenchyma projecting inwards. There is no such sculpturing in any of the five species of Marattia studied, so that as far as they are concerned the genus is distinguished from Angiopteris by this histological feature. In Danaea elliptica, however, an almost identical state of matters is met with in the fertile, but not the barren fronds. This is very curious and difficult to explain. It is evident therefore that the arrangement of the elements of the sclerenchyma may have some diagnostic value. This difference in the sclerenchyma of the fertile and barren fronds of Danaea elliptica is one example of the many pitfalls and snares which beset the path of the palaeophytologist.

(2) Mucilage-canals. Although in general there is no specially characteristic arrangement of the mucilage-canals, all the same, one species of Marattia showed a distinctive peculiarity in this respect, viz. $M$. cicutaefolia. In this species only was found in the pulvinus a ring of mucilage-canals lying between the collenchyma and the epidermis.

(3) Tannin-sacs. The number and arrangement of these structures vary a good deal in the different species, and it was at first thought they would be useful as systematic guides, but revision of the matter showed that there is not sufficient constancy and definiteness in arrangement to be of real value. However, careful plotting of their position and comparison of the arrangement in the different species might occasionally aid specific discrimination. Tannin-sacs, for instance, are abundantly present round the meristeles in the pulvinus of $M$. cicutaefolia and $M$. attemuata, and they are practically absent in the pulvinus of $M$. fraxinea. The section from which Fig. I I was drawn had only two quite indefinitely placed tanrin-sacs.

No attempt was made to test the distribution of crystals from this point of view, although in the hands of Radlkofer 
they have been shown to be of real use in aiding specific distinction in certain cases. The crystals and mineral deposits of the Marattiaceae have been studied by several observers, e.g. in more recent times Montverde, Kühn, and Radlkofer.

The structure of the meristeles, although distinctive of the group, does not afford means of generic or specific distinction. Taking the Marattiaceae collectively it may be said that they do not possess many diagnostically valuable histological characters.

The petiole and rachis are generally somewhat flattened on the upper surface. In the rachides, especially of the second and third order, there are projections from the angles, and there is a median ridge which becomes more prominent towards the apices. In some species the lateral ridges become wing-like, hence the specific term alata. These are specially mentioned because they are the only parts of the axes which have numerous rodlets projecting into the intercellular spaces from the walls of the cells. The rodlets however occur abundantly in the mesophyll of the lamina. It looks just as if there had been a viscid mass between the cell-walls, so that when the intercellular spaces were formed, it was drawn out into stringy masses, the threads of which parted in the middle as the walls receded from each other. According to Mangin ${ }^{1}$ these rodlets consist of pectates, chiefly calcium pectate. Whereas these rodlets are very well marked in Angiopteris, Marattia, and Kaulfussia, they are almost, if not quite, absent in Danaea simplicifolia and elliptica, although present in other species.

In none of the genera do the meristeles of the leaf differ essentially from those of the stem. The chief difference is in the position of the protoxylem, which is normally endarch in the frond, endarch and mesarch in the dictyomeristeles ${ }^{2}$. In a few cases two or three xylem-elements (PI. XXIII, Fig. 22, $\left.m x x^{\prime}\right)$ were found to the inside of the protoxylem,

1 Mangin, Étude historique et critique sur la présence des composés pectiques dans les tissus des végétaux, Journ. de Bot., v. I89I, vi. I892.

2 Shove, loc. cit., p. $5^{\mathrm{I}} 3$. 
so that the protoxylem becomes mesarch. Figs. 20, 2 I and 22 show the structure of the leaf-meristeles in Marattia attemuata, Kaulfussia aesculifolia and Danaea alata respectively. These figures show that the structure of the meristeles is practically identical in the different genera. The difference in shape is not distinctive, because in any one species all these forms may be found, not to mention others. Fig. 20 was drawn from a secondary rachis of $M$. attenuata near its base, Fig. 2 I from a leaflet-midrib of Kaulfussia, and Fig. 22 from the petiole of Danaea alata. The most interesting point in connexion with them is the extension of Miss Shove's interesting discovery of the endarch position of the protophloem in the meristeles of the stem of Angiopteris to the leaf-meristeles of the Marattiaceae generally. If the leaf-meristeles (in transverse section) of an adult frond be examined, there is very little evidence of the protophloem, but in stained preparations an irregular line of darker walls, especially thick at the angles where certain cells appear to meet, are noticeable near the outer border of the xylem. This layer was early observed but its cause was left for future investigation. In the meantime Miss Shove published her discovery in the stem of Angiopteris, and it at once became clear that this line ( $p p h$. in Figs. 20, $21,22)$ was due to the obliterated protophloem. That this was really the case was subsequently proved in Marattia alata, pph. Fig. 18. Sections of young fronds of Angiopteris evecta and Marattia cicutaefolia, made in connexion with the mucilage-canal investigation, show this endarch position of the protophloem very clearly, but it was overlooked at the time.

The structure of the sieve-tubes themselves has been so exhaustively dealt with by Poirault ${ }^{1}$, that it is superfluous to do more than quote his results. He found that there are two types of sieve-tubes, the Cucurbita-type, with a single plate on the transverse wall, and the vine-type with very

${ }^{1}$ Georges Poirault, Recherches sur les cryptogames vasculaires, Ann. Sci. Nat., $2^{\mathrm{e}}$ sér., Bot., xvii-xviii, 1893 , p. I 38 et seq., and p. 192 . 
oblique end-walls, the number of plates varying with the obliquity of the wall. Besides these plates, isolated pits (ponctuations), or small groups of them, occur on the longitudinal walls. The contents of these sieve-tubes is a highly refringent liquid containing a number of refringent sphaerules in suspension, which are specially aggregated in the region of the pits. The wall consists of cellulose. The sieve-plates and pitted areas are actually perforated. No callus occurs.

The exceptional position of the protophloem in this group of Ferns is very remarkable, and it is matter for wonder and speculation why the Marattiaceae alone, so far as is known, possess it. A reason for its position can readily enough be found, viz. the more ready conduction of nitrogenous foodmaterial to the developing xylem on the one hand, and the later formed phloem on the other. Once the advantage of such an arrangement is realized, the puzzle is not why should the Marattiaceae show this peculiarity, but why do not many other Pteridophyta and Spermophyta show it likewise? The internal phloem is developed a good deal later, and it has no protophloem, the protophloem only occurring on the outer face of the xylem and occasionally only just turning the corner at the ends of the xylem-plate .

In the Marattiaceae, as in other cases among Ferns, the concentric type of meristele which is characteristic of the frond generally, becomes collateral in the finer veins. In this there is a return to the condition found in the seedling, in which, at any rate in Danaea simplicifolia, the first veins have no phloem on the inner or upper side. Fig. 23 illustrates one of the lateral veins of a fair-sized frond of Danaea simplicifolia, near its base. The meaning of the xylem being broken up into three parts could not be ascertained. It was thought that it might be associated with the dichotomy of the veins, but the same arrangement occurs above as well as below the fork. Fig. 24 shows still further reduction of the phloem, and at the same time another case of endarch protoxylem. The section was made from a fine vein of Marattia cicutaefolia.

1 Cf. Shove, loc. cit., p. $5 \mathrm{I} 3$, par. 3 . 
Fig. 25 illustrates a similar vein in longitudinal section, and proves that the protoxylem is really endarch.

Finally, the occurrence of 'cavity parenchyma' in the leaf may be mentioned. A not particularly good example is shown at $c p$., Fig. 22. The cavity due to the breaking down of the protoxylem is filled with parenchyma, owing to the increase in size, accompanied by a greater or less amount of division, of the adjacent living cells. It is practically a case of thylosis, only that the process is not accompanied by so much cell-division, and it is not the protoplasts but the cells as a whole that grow into the space. In this instance the internal xylem has been separated from the protoxylem in the process. It is probably not of any physiological importance, being simply a case of non-pathological hernia, so to speak.

\section{The Stem.}

In view of the recent work on the stem of Angiopteris and Marattia there is very little more to be said about its histology. The meristeles, as has already been pointed out by Kühn and others, whether of the dictyostele or the outgoing leaf-traces, are practically identical in structure in all the genera. Although not easily expressed in words, these meristeles have a sufficiently characteristic appearance to enable them to be distinguished from those of most other Pteridophyta. This is partly due to the absence of the endodermis round the outgoing leaf-trace meristeles of the stem, and its apparent ${ }^{1}$ absence round the dictyomeristeles themselves. Besides finding it round the meristeles of the seedling, Farmer and Hill were able to demonstrate its presence in the older stem in Angiopteris, Marattia and Kaulfussia ${ }^{2}$. The fact that it is absent round the outgoing leaf-traces, after they have become quite free from the dictyostele, may account for the older observers having overlooked it, because they probably did not distinguish

1 The endodermis, even where most marked, as in the seedling-stem, cannot be detected without staining or other micro-chemical means.

2 Loc. cit., p. $3^{86 .}$ 
between the outgoing leaf-trace meristeles and those of the dictyostele. Miss Shove, however, was not able to demonstrate the endodermis in relation to the 'stem steles' (dictyomeristeles) of the well-grown plant which she examined.

The arrangement of the strands in the stem, except in the case of Danaea simplicifolia seedlings, was not gone into. From the earlier, and especially more recent, work in this line it is now possible to form a good idea of the general arrangement of the vascular system of these plants. Farmer and Hill's models of the arrangements in Angiopteris and Marattia seedlings ${ }^{1}$ mark an epoch in this study and are exceedingly helpful. To sum up then, these plants have a more or less complex adelosiphonic dictyostele, which is developed from a haplostele by the formation of leaf-gaps and a considerable tendency of the meristeles to branch and anastomose.

No further information was gleaned with regard to the apical cell by the work done on Danaea simplicifolia seedlings. Farmer and Hill (loc. cit., Pl. XVI, Figs. I4 and I5) seem to have got satisfactory evidence that in the seedlings of Angiopteris there is a single apical cell, and the writer came to the same conclusion with regard to the embryo of Danaea simplicifolia. But there is still room for further work in this direction. Farmer himself ${ }^{2}$ and Bower ${ }^{3}$ have both supported the oligocellular view. This is one of those questions to which it is very difficult to get a definite answer, perhaps because there is none, on account of the structures being still in a state of flux, so to speak.

\section{The Root.}

There is little variation in the root-structure throughout the group. Miss Shove, in her recent paper, has figured the

${ }^{1}$ Loc. cit., Plates XVI and XVII.

${ }^{2}$ J. B. Farmer, On the Embryogeny of Angiopteris evecta, Ann. of Bot., vi, p. 267 .

3 Bower, Comparative examination of the meristems of Ferns, Ann. Bot. iii, pp. 324,325 . 
polyarch actinostele of the aerial roots of Angiopteris. The subterranean roots only differ in the smaller number of the alternating groups of xylem and phloem, and slightly in texture of the cortex. The structure of the oligarch central cylinder of Angiopteris is practically identical with that of the fossil genus Psaronius, which is considered to have Marattiacean affinities ${ }^{1}$. It is unnecessary here to go into the structure of the actinostele of these plants since it has been so recently illustrated and described, nor is it desirable to give details of the varying number of the alternating protoxylem and phloem groups in the different genera. There remains, therefore, only to be mentioned one or two slight anatomical differences, which are of more or less diagnostic value. As noted by Harting, in the celebrated de Vriese and Harting monograph, there are very thick-walled sclerotic cells sparingly distributed in the cortex of the subterranean roots, and this seems to be generically characteristic. In Danaea Kühn found a sclerenchymatous pith ${ }^{2}$ in the various species examined by him, but curiously enough a few specimens of Danaea alata, Sm., did not have it. The thick-walled fibres constituting this pith are differentiated early (cf. Fig. 26, Pl. XXIII). Danaea also has a continuous ring of sclerenchyma fibres two or three cells thick lying a few cell-layers below the epidermis. The protoxylem may abut directly on the endodermis in the older as well as in the primary and earlier cauline roots. In the figure this is seen to be the case with the protoxylem adjacent to the endodermal cell marked en.

In the article Marattiaceae of Engler and Prantl's Natiirlichen Pflanzenfamilien, the development of the tracheae of the roots is said to be centrifugal ${ }^{3}$. After this was noticed there was no time to go into the matter practically, but the order of lignification of the tracheids is undoubtedly from without

1 Cf. D. H. Scott, Studies in Fossil Botany, p. 268 et seq., and Farmer and Hill, loc. cit., p. 268 et seq.

${ }^{2}$ R. Kühn, Ueber den anatomischen Bau von Danaea, Flora, 1890.

3 Loc. cit., p. 43 o. 
inwards, or centripetal (cf. Fig. 26). Moreover, it is difficult to understand what is meant by the statement that the tracheae are simultaneously developed in a quadri-radiate manner in the centre, and that subsequently smaller thick-walled tracheae are added partly in secondary rays ${ }^{1}$. There can be no question of a constantly quadri-radiate central differentiation, because all types of root from the diarch to the polyarch are formed in the course of the development of the seedling to the full-grown plant. The writer observed nothing in the many roots examined, both young and old, which suggested anything different from the normal development of a root central-cylinder, or actinostele.

\section{Mucilage Canals.}

The lysigenous view of the development of these structures has again found strong support, for Farmer and $\mathrm{Hill}^{2}$ throw in the weight of their opinion in its favour.

The writer advocated the schizogenous view as a result of his examination of the development of those structures in the root and frond of species of Marattia and root of Danaea simplicifolia. A careful re-examination of the preparations originally made seems to the writer to still justify his belief in the schizogenous origin of these structures, but the sections were hand-cut, and there is always the risk that something may have dropped out. On the other hand, microtomeseries made from material imbedded in paraffin and cut by the 'rocker' are not quite satisfactory, because the sudden impact on the knife-edge breaks the epithelial walls, and frequently displaces the cell-contents. It seems to the writer that the only means of satisfactorily settling this question is to imbed in celloidin and cut with a sliding microtome.

\section{REVIEW OF TERMINOLOGY IN RELATION TO MORPHOLOGY.}

As indicated in the introduction on terminology, certain of

1 'Die primären Gefässe werden in Form eines Vierstrahlers im Centrum gleichzeitig angelegt, später schliessen sich daran dickwandigere, kleinere Gefässe, teilweise in secundären Strahlen.'

${ }^{2}$ Loc. cit., p. 390. 
the older and more recent conceptions of the morphological importance of certain histological layers are being abandoned. Farmer and Hill point this out with regard to the endodermis and histogenetic layers, and Pitard ${ }^{1}$ expresses himself as follows with regard to the pericycle: 'Cette notion' du péricycle apparaît donc en définitive comme inadéquate aux faits et sans utilité pour l'expression.' The writer is quite in accord with these views, and thinks these layers should be, in many cases, abandoned as morphological criteria.

The new terms put forward tentatively have been based almost entirely on the idea of the stele as originally set forth by Van Tieghem. In view of the writer's belief in the unimportance of the endodermis, pericycle, \&c. as morphological criteria, it is somewhat doubtful if the method adopted was a wise one. It would perhaps have been better to abandon the stelar theory altogether, and substitute for it the conception of a connected system of vascular strands on the one hand and non-vascular tissue on the other. At the same time the non-vascular tissue would not be considered as something essentially and fundamentally different from the vascular, for they are both differentiated from the same meristem, and what has become vascular in one case might very well be non-vascular in another or vice versa. To take one illustration: in most Dicotyledons the pith is simple with no vascular strands, but in some cases there are what are called 'medullary bundles.' Therefore the pith in Dicotyledons may be said to be potentially vascular. It is undesirable to apply the term stele to the suggested conception of the vascular system, but perhaps another and suitable term may be found which could be combined with the prefixes already used to distinguish the different stelar systems. They could further be appropriately dealt with as follows:-The vascular system of typical Dicotyledons would be described as cyclodesmic, Monocotyledons as atactodesmic, the vascular network of Ferns as dictyodesmic, and so on. These terms might even

1 Pitard, 'Le péricycle et la taxonomie : valeur anatomique du péricycle,' Actes de la Société Linnéenne de Bordeaux, sér. vi, t. vi, r9or, p. 43-6r). 
be used at the present time; in fact, 'mondesmic' has already been used by Scott in his 'Studies in Fossil Botany' ${ }^{1}$ in the sense of possessing one strand. It would unnecessarily expand this paper to discuss the various additions to botanical knowledge which are bringing about this change of attitude. Perhaps the time is hardly yet ripe, but the day does not now seem far off when the three histogenetic layers, as well as cortex, pith, endodermis, pericycle, \&c., will have lost to a great extent their present morphological connotation and be used simply as convenient descriptive terms in certain cases.

\section{RÉSUMÉ AND CONCLUSIONS.}

Development of the Vascular System of Danaea. The vascular system is developed from a simple type of stele, a haplostele. The haplostele does not pass through a medullated stage, but becomes crescentic after the successive departure of a variable number of leaf-traces. When this stage is reached the next leaf-trace passes off from the convexity of the crescent, thus causing a distinct leaf-gap. Two meristeles are left behind with what is usually considered extrastelar tissue between them. The crescent gap is closed, a leaf-trace is given off, the gap again closed, \&c. By the repetition of this process, followed by branching, anastomosis, and increase in number of leaf-trace meristeles, at length a network of strands or the dictyostele is formed. At one level or another a transitory solenostelic stage intervenes owing to the closure of one leaf-gap before the next one is opened. Also at no very definite level a strand arises as a branch from the concavity of the crescent, pursues an upward spiral course anastomozing with the large gamomeristele formed to close the successive leaf-gaps, so to speak, and at the same time give rise to the root. This central commissural column, or central strand, later gives off two branches which however reunite on their upward course. In this way then the irregular stelar network of Danaea simplicifolia is built up, and is shortly expressed by the statement that it is an adelosiphonic dictyo-

${ }^{1}$ 1. c., p. 303 .

$\mathrm{P} \mathrm{p} 2$ 
stele developed from a non-medullated haplostele by an early formation of overlapping leaf-gaps accompanied by branching and anastomozing of the meristeles.

The only point in which Danaea differs essentially from Angiopteris and Marattia is in not passing through a medullated stage before the commencement of the formation of the dictyostele. There can be little doubt that Kaulfussia and Archangiopteris pass through a similar stage, and in a very similar manner.

Comparative Anatomy of the Marattiaceae. The result of the study of the comparative anatomy is broadly that there is a great amount of uniformity in internal structure. They are all adelosiphonous with a greater or less tendency to dorsiventrality in Angiopteris, Marattia and Danaea. In the last-named it is distinctly marked and practically complete in Kaulfussia (Kühn, and Farmer and Hill). In the young sporophyte of the three first-named the symmetry is radial.

The meristeles of the stem and leaf are practically identical in structure. The veins of the first leaf are collateral, as also the ultimate ramifications of the veins of the young and adult fronds.

The protoxylem seems to be normally endarch and mesarch in the stem, endarch in the frond. A very imperfect mesarch condition also quite exceptionally occurs in the larger leaf meristeles, and occasionally in the fine veins.

The root-structure, as already stated, is practically identical throughout the family. The aerial roots of Angiopteris and Marattia are polyarch and their subterranean portions oligarch. In Danaea alata, and presumably many others, the adult roots are polyarch. In Angiopteris there are very thick sclerotic cells sparingly present in the cortex and there is a mid-cortical ring of sclerenchyma in Danaea. Danaea also has a medullary strand of sclerenchyma fibres, which differentiate very early. The roots of Archangiopteris and Kaulfussia were not examined, but the latter are described by Kühn and are tetrarch to pentarch, but not otherwise essentially different. 
For a good résumé of the chief literature and an excellent general account of the Marattiaceae the reader is referred to the article in Engler and Prantl's 'Naturlichen Pflanzenfamilien.'

Other Histological Details. Certain of these were found to be of some use for generic and specific distinction, e. g. structure of sclerenchyma, but only to a limited extent.

Finally the writer cannot express too strongly his great indebtedness to Dr. D. H. Scott for his constant interest, encouragement and advice during the course of the investigation. Mr. L. A. Boodle also gave much assistance by helpful discussion and references to literature.

\section{EXPLANATION OF FIGURES IN PLATES XXII AND XXIII.}

Illustrating Mr. Brebner's Paper on the Anatomy of Danaea and other Marattiaceae.

\section{Abbreviations.}

alb. albuminous cell (?); col. collenchyma; $c p$. cavity parenchyma; en. endodermis ; en.' internal endodermis; $l t$. leaf-trace; $m c$. mucilage canal; ms. meristele ; $m x$. xylem; $m x .^{\prime}$ xylem formed to inside of protoxylem ; $p a$. parenchyma; $p x$. pericycle; $p h$. phloem; $p$ ph. protophloem.

Figs. I-IO and 19 are from microtome series of Danaea simplicifolia seedlings. The radial walls of the endodermis are indicated conventionally.

Figs. I-4. From very young seedling showing formation of leaf-trace. ( $\times 242$.

Fig. 5. Section from the same seedling showing departure of the first two leaftrace meristeles and the approach of a root. ( $x$ II 4 .)

Fig. 6. Section from a seedling showing abnormal preparation for the departure of several leaf-traces almost simultaneously. ( $x$ 212.)

Fig. 7. Section from the stem of a seedling with an abnormally long internode near the base. It clearly shows the endodermis round the stele and leaf-trace meristele. The stele is preparing for the departure of the next leaf-trace. ( $\times$ I 82 .)

Fig. 8. Section from the same seedling. It shows an almost solenostelic stage owing to the junction of a root. ( $\begin{aligned} & x \\ & 242 .)\end{aligned}$

Figs. 9 and 10. Sections from the same seedling showing departure of the next leaf-trace. $\left(\times 24^{2}\right.$. $)$ 
Figs. I I and I 2. Marattia fraxinea. Primary pulvinus and petiole in transverse section. ( $x$ 5.)

Fig. I3. Marattia fraxinea. Section of petiole. just below first pair of pinnae. $(\times 5$.

Fig. I4. Marattia fraxinea. Pulvinus of secondary axis on one side. ( $\times 5$.

Fig. I5. Marattia fraxinea. Pulvinus of secondary axis on the other side. $(\times 5$.

Figs. 16 and 17 . Marattia fraxinea. Secondary rachis near the apex. $(\times 5$.

Fig. 18. Marattia alata. Transverse section of meristele of developing petiole to show the protophloem, $p$ ph. $\left(\times 3^{18 .}\right)$

- Fig. I9. Danaea simplicifolia. Solenostelic stage from the same series as figs. 7-10. ( $\times 238$.)

Fig. 20. Marattia attenuata. Transverse section of meristele from secondary rachis near base. ( $X$ I $3 \mathrm{I}$.)

Fig. 21. Kaulfussia aesculifolia. Transverse section of meristele from leaflet midrib. ( $X$ I 3 I.)

Fig. 22. Danaea alata. Transverse section of petiolar meristele. (X I3I.)

Fig. 23. Danaea simplicifolia. Transverse section of lateral vein near base. ( $x$ 200.)

Fig. 24. Marattia cicutaefolia. Transverse section of lamina showing fine collateral vein with endarch protoxylem. $(\times 200$.

Fig. 25. Marattia cicutaefolia. Longitudinal section of similar vein. $(x$ 200.)

Fig. 26. Danaea simplicifolia. Transverse section of incompletely differentiated actinostele of young root. $(x$ 200.) 
en

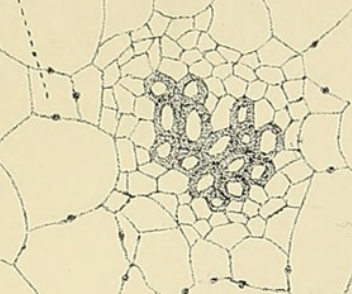

1

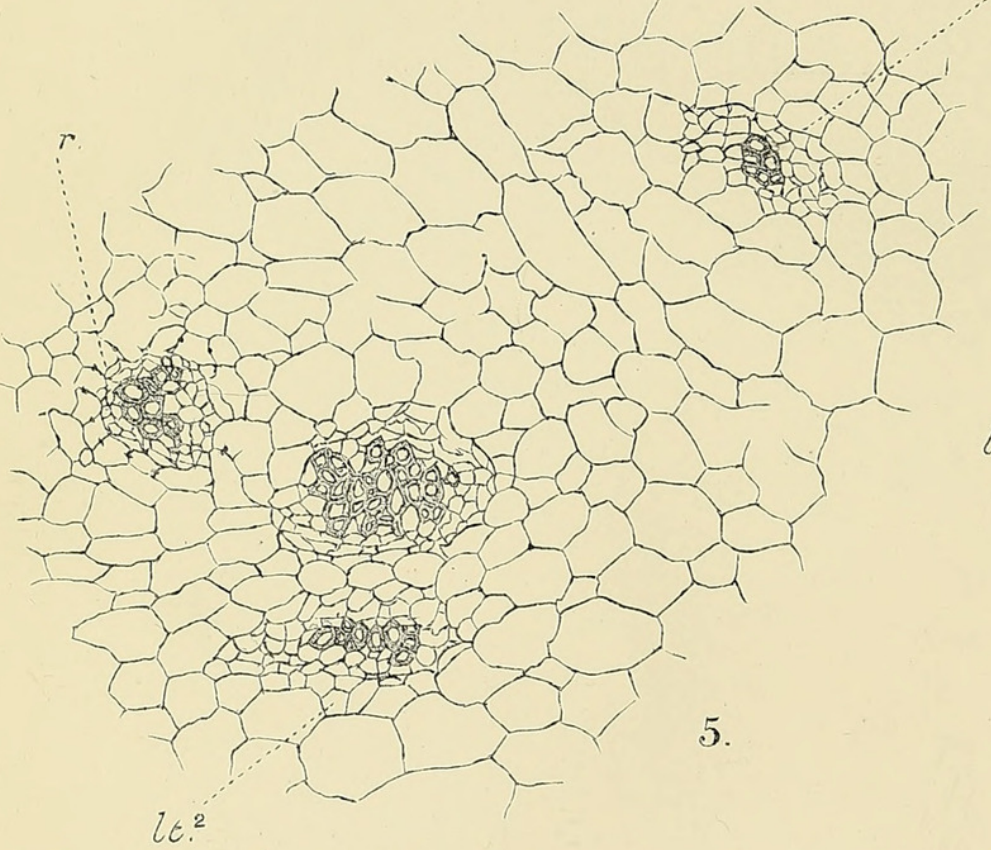

$l t^{2}{ }^{2}$

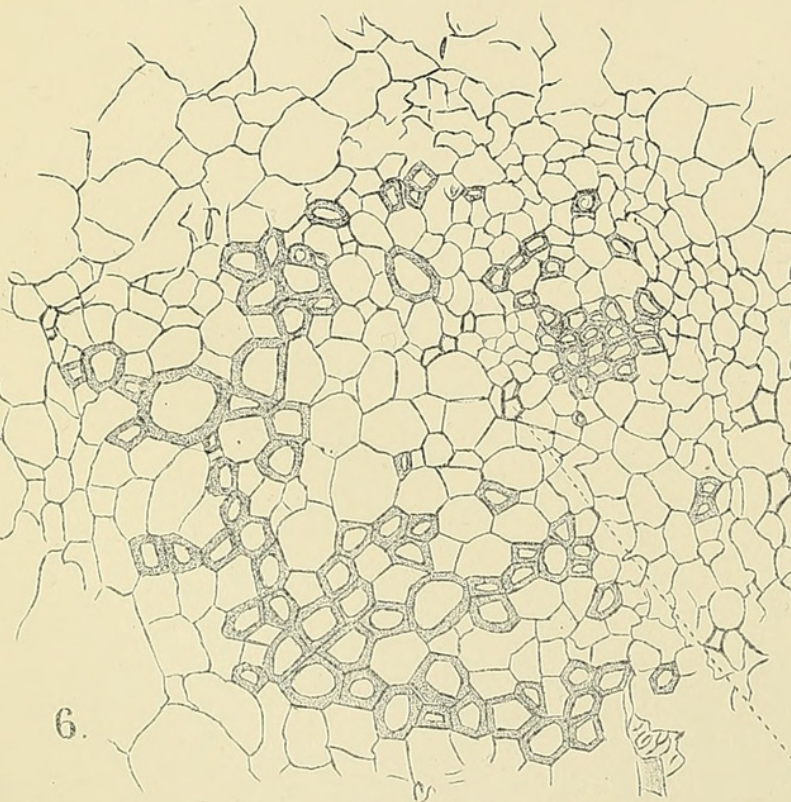

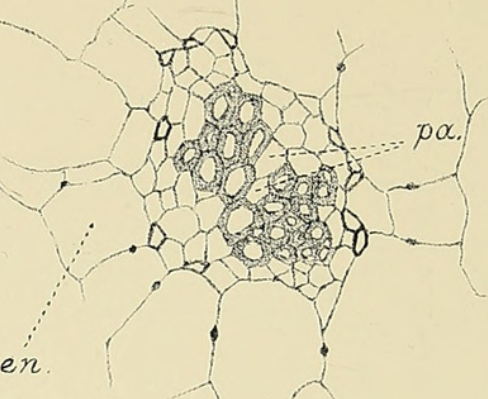

2.

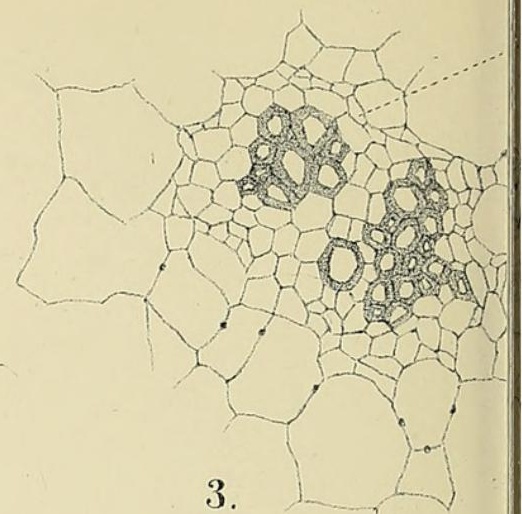

$l t^{\prime}$
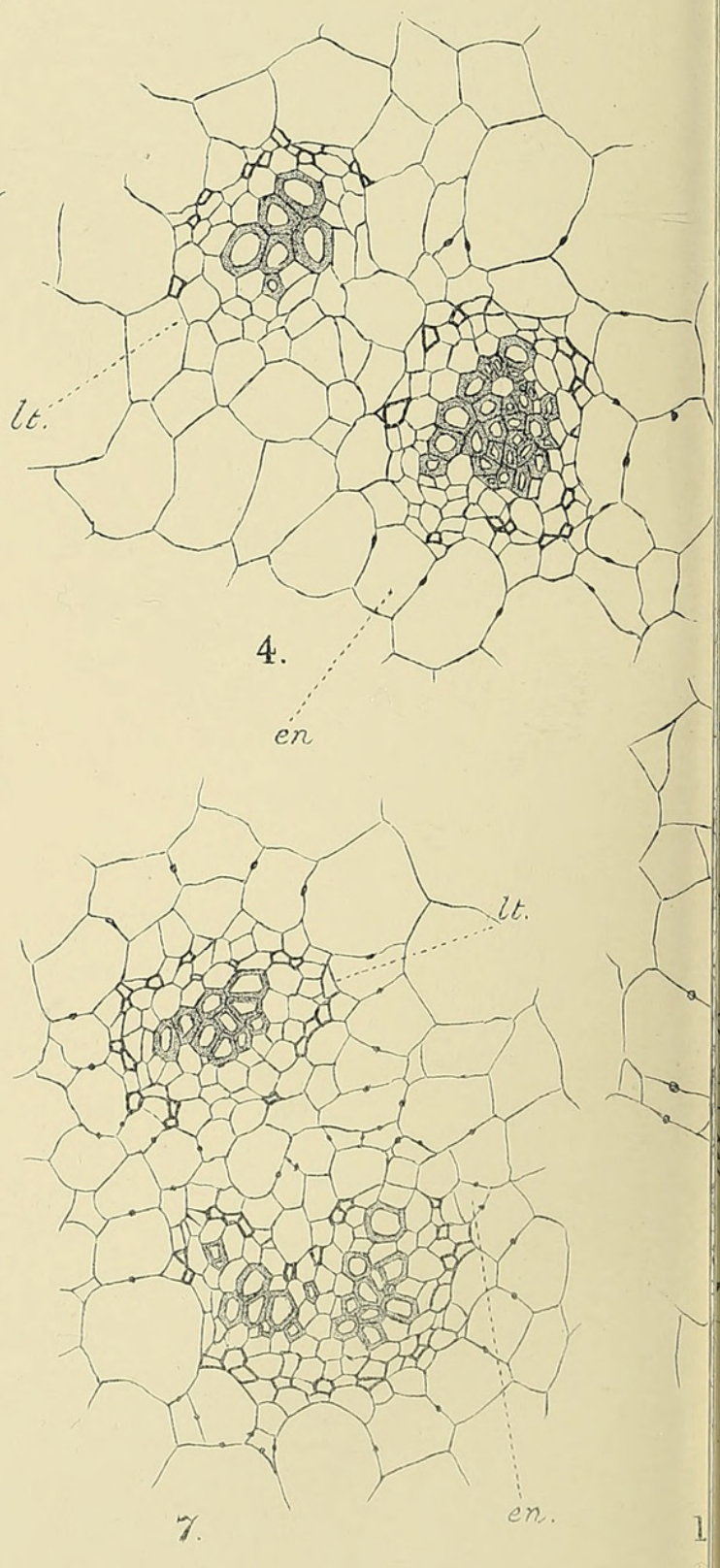


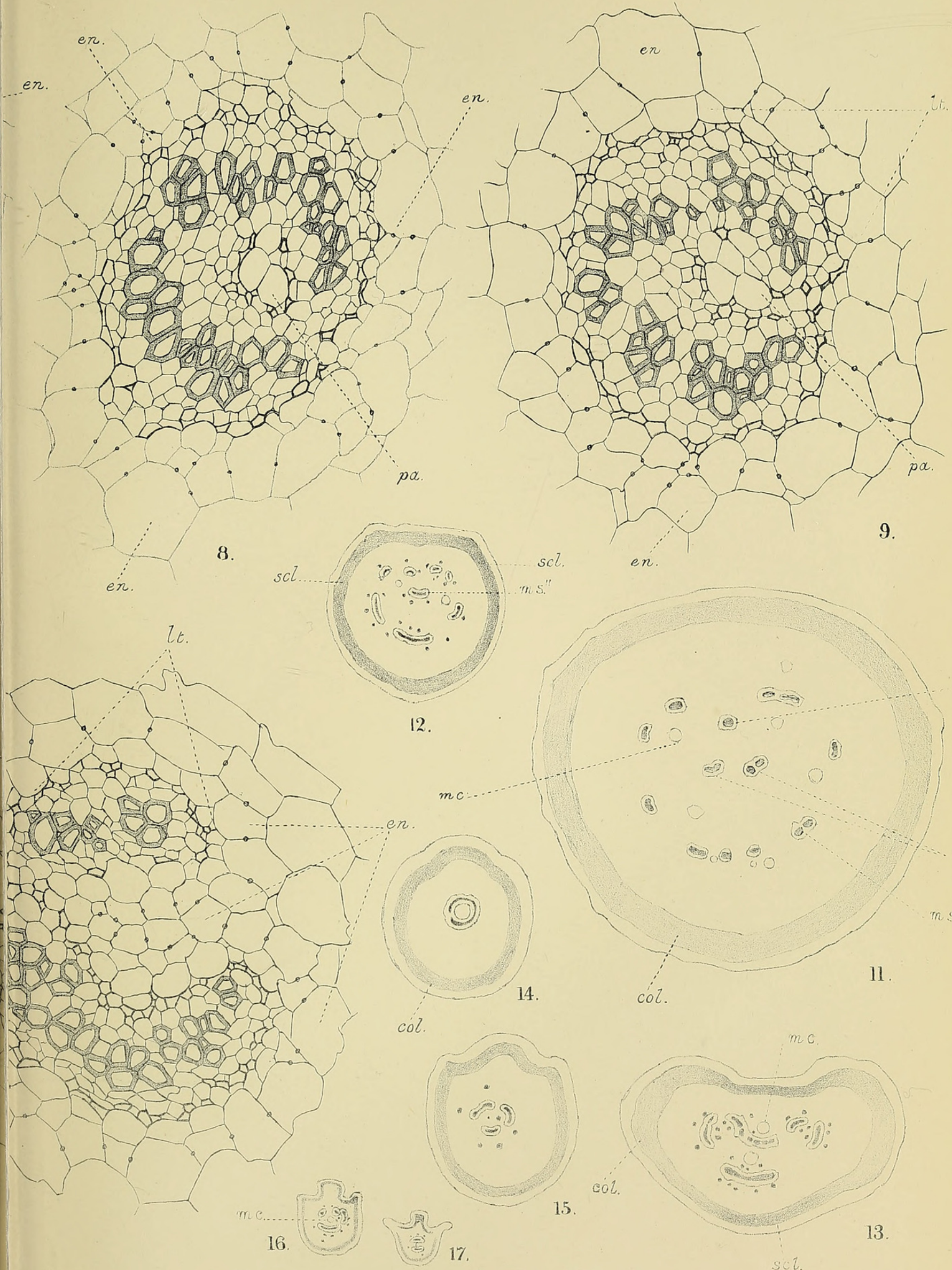



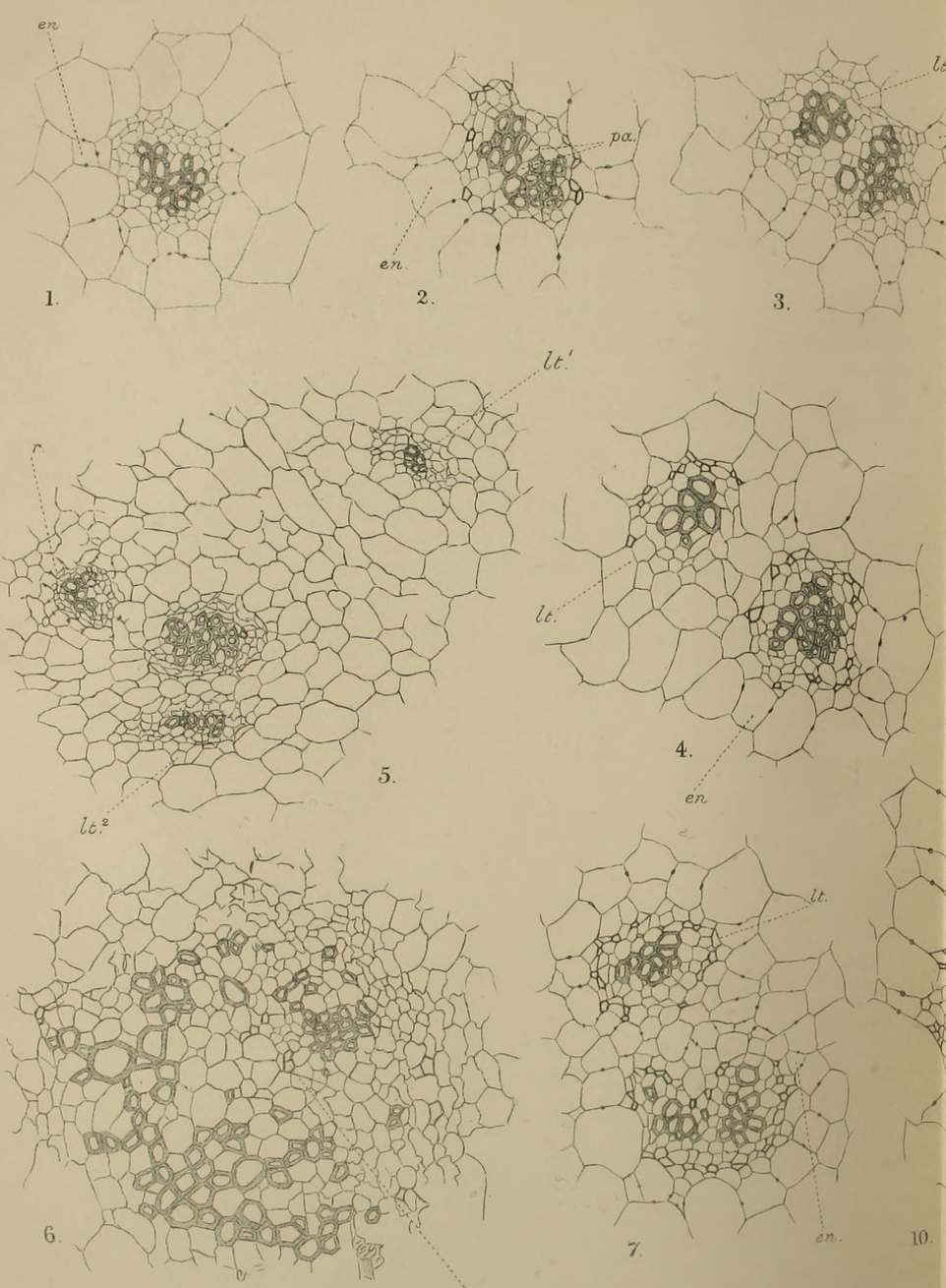

10.

$\sqrt{2}$

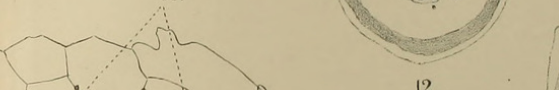

12.

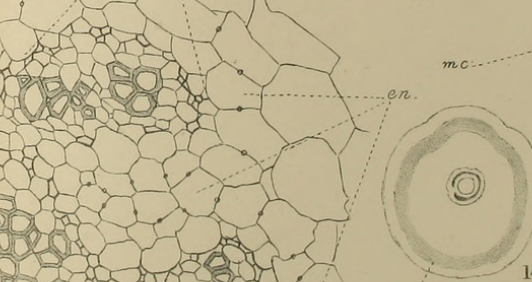

10



1

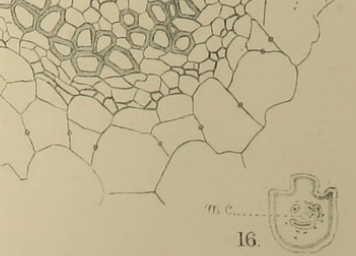

coll

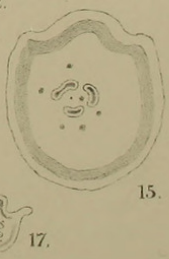

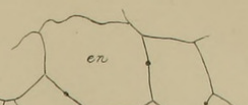
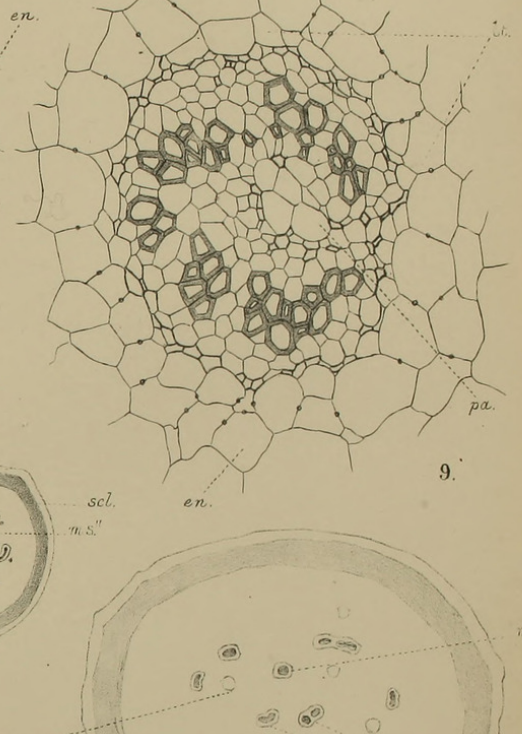

(8)

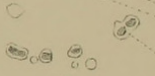

11

col.

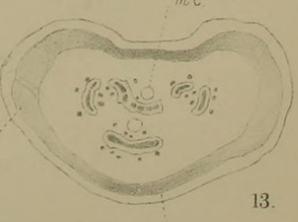

13. 
Annals of Botany
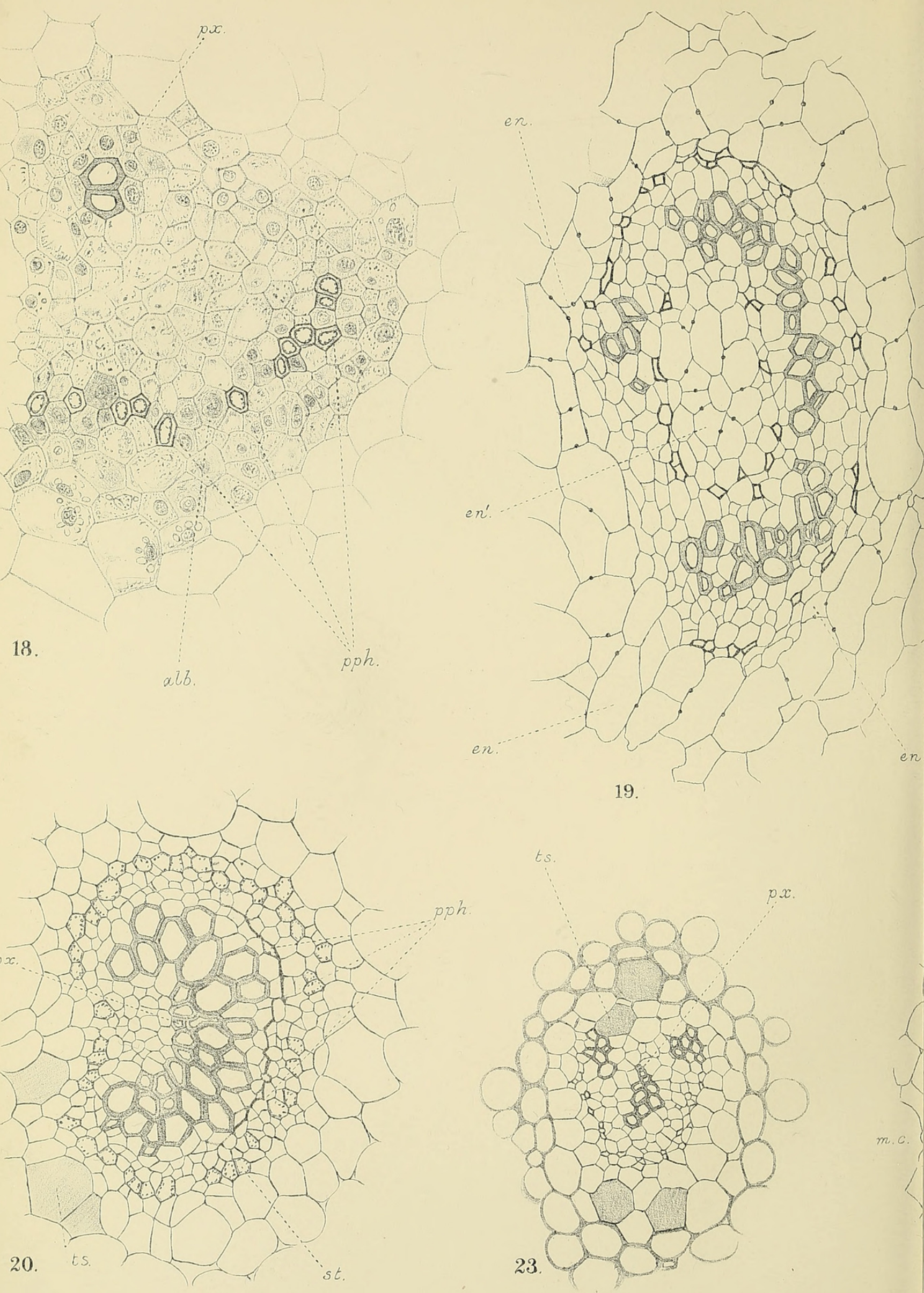


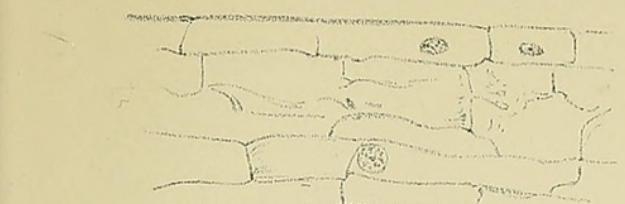

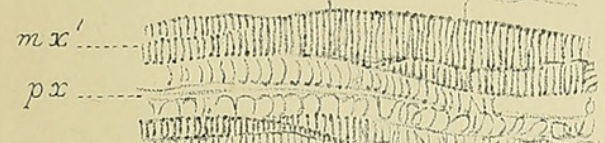

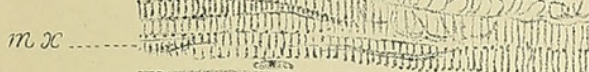

2 d d
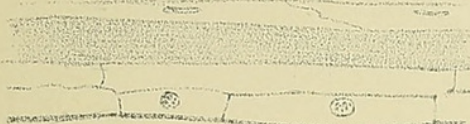

25.
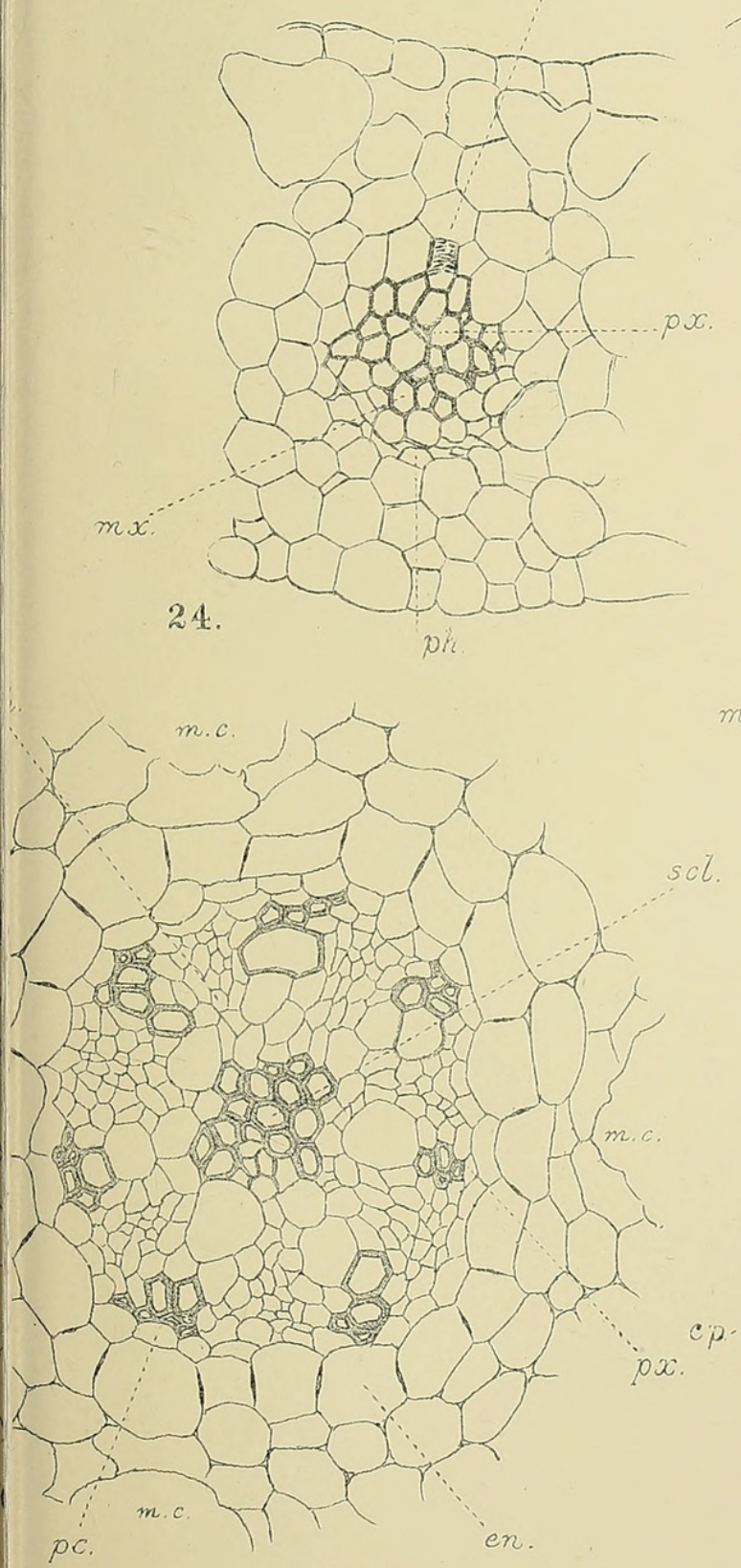

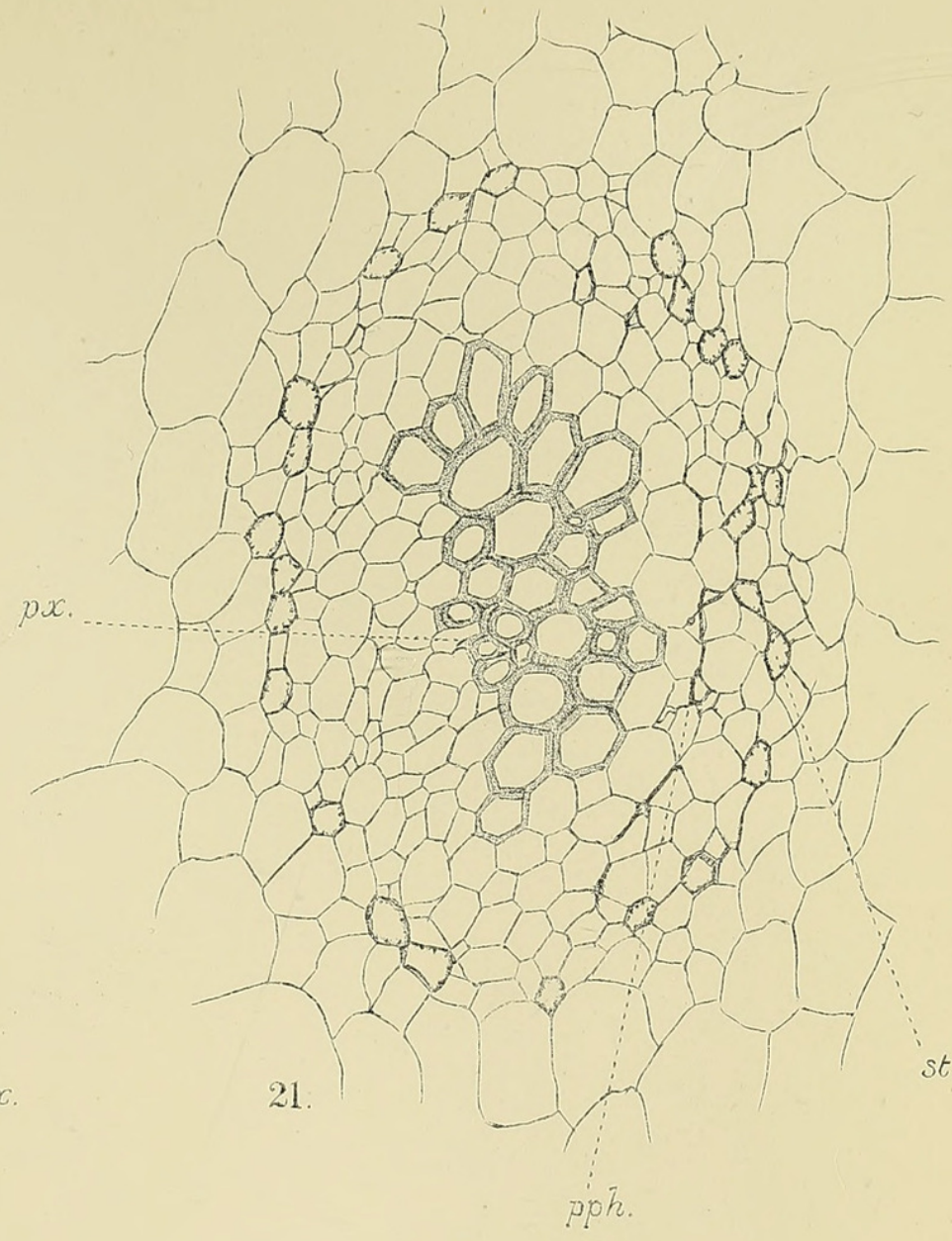

st

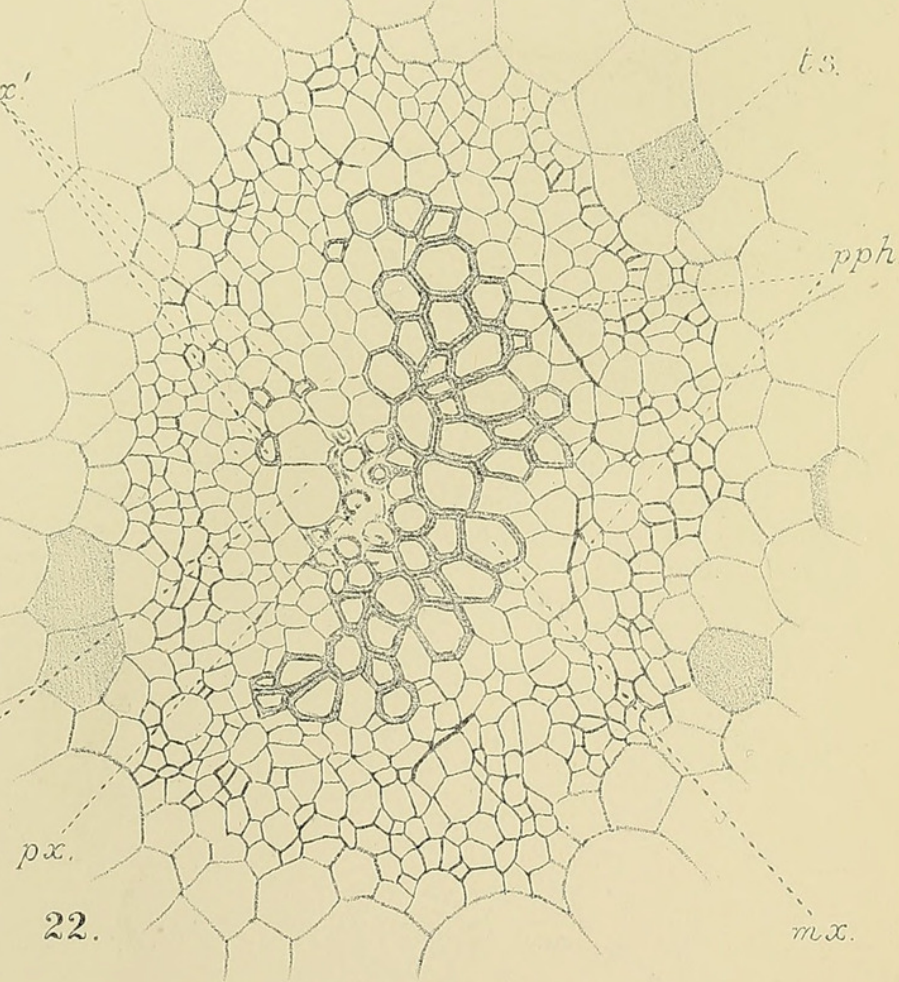




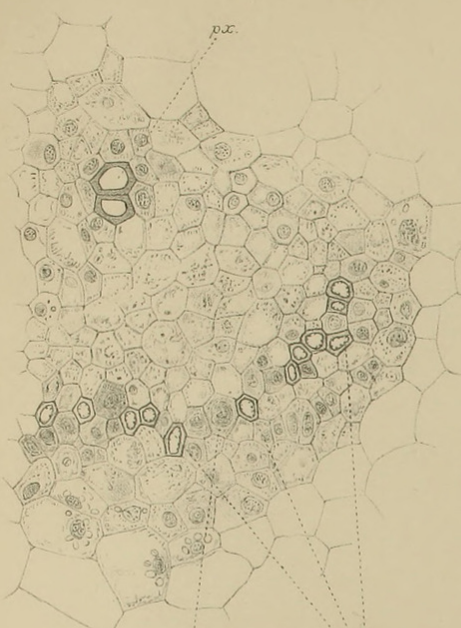

18.
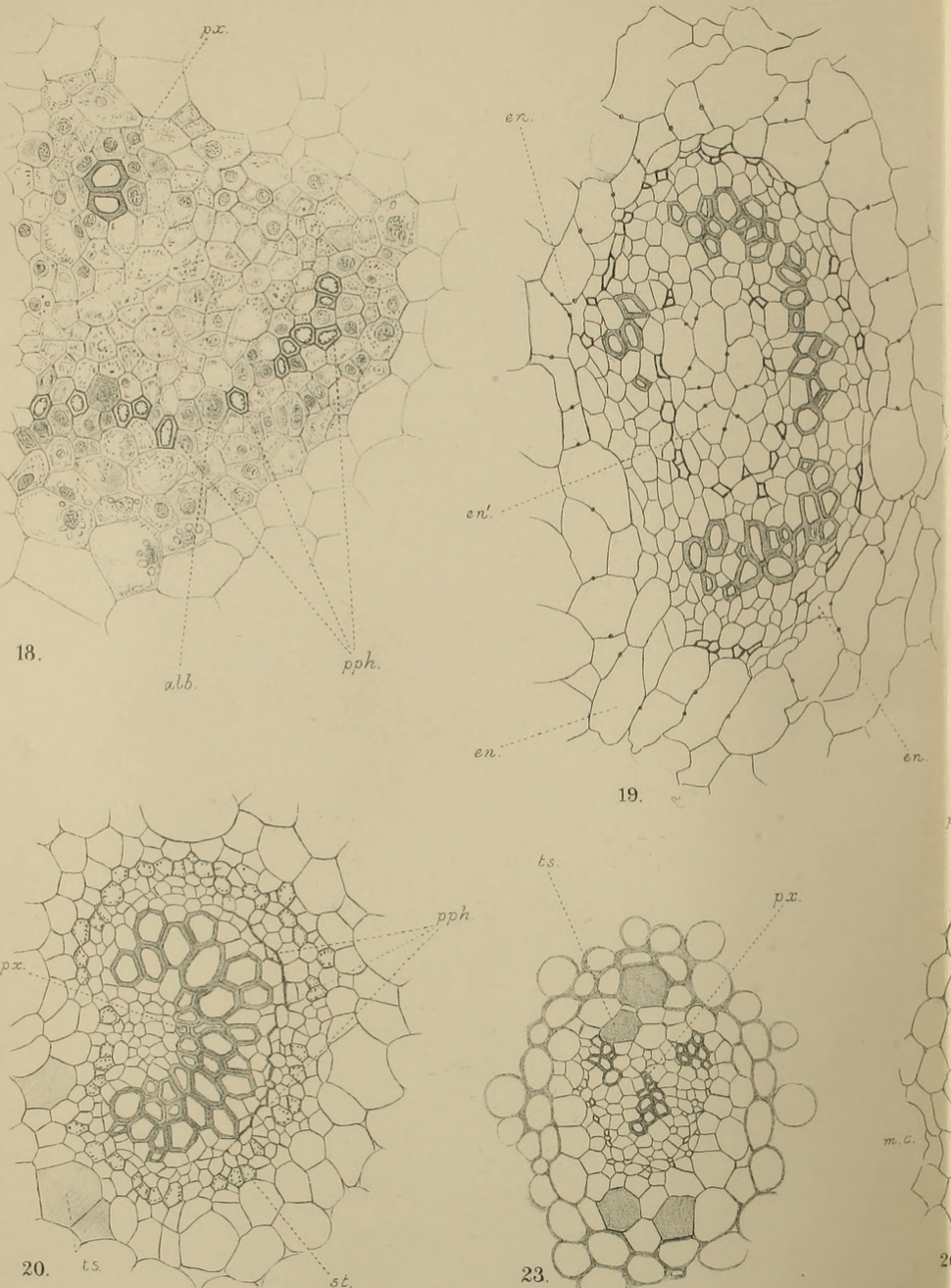

pph
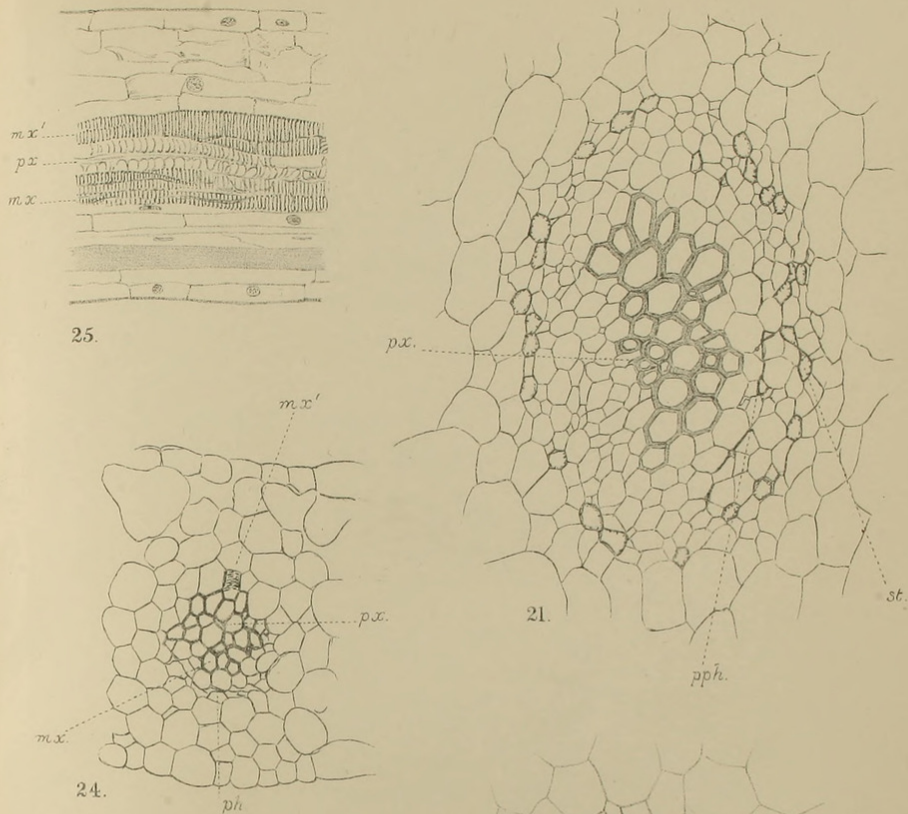

pph.

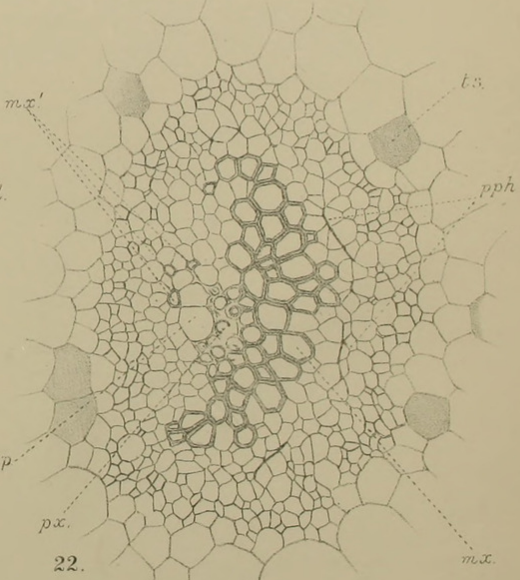




\section{$2 \mathrm{BHL}$ Biodiversity Heritage Library}

Brebner, George. 1902. "On the anatomy of Danaea and other Marattiaceae." Annals of botany 16, 517-552.

https://doi.org/10.1093/oxfordjournals.aob.a088887.

View This Item Online: https://www.biodiversitylibrary.org/item/233980

DOI: https://doi.org/10.1093/oxfordjournals.aob.a088887

Permalink: https://www.biodiversitylibrary.org/partpdf/318688

\section{Holding Institution}

Smithsonian Libraries

\section{Sponsored by}

Biodiversity Heritage Library

\section{Copyright \& Reuse}

Copyright Status: Not in copyright. The BHL knows of no copyright restrictions on this item.

This document was created from content at the Biodiversity Heritage Library, the world's largest open access digital library for biodiversity literature and archives. Visit BHL at https://www.biodiversitylibrary.org. 